\title{
Gestational Cd Exposure in the CD-1 Mouse Sex-Specifically Disrupts Essential Metal Ion Homeostasis
}

Thomas W. Jackson¹ (ORCiD: 0000-0002-7996-0412), Oliver Baars² (ORCiD: 0000-0002-46445086), and Scott M. Belcher (ORCiD: 0000-0002-1196-3705) 1*

1 Center for Human Health and the Environment and Department of Biological Sciences, North Carolina State University, North Carolina State University, 127 David Clark Labs Campus Box 7617, North Carolina State University, Raleigh, North Carolina, USA

2 Department of Entomology \& Plant Pathology, North Carolina State University, Raleigh, North Carolina, USA

\author{
Email Address: $\quad$ Thomas W. Jackson: twjacks2@ncsu.edu \\ Oliver Baars: obaars@ncsu.edu \\ Scott M. Belcher: smbelch2@ncsu.edu \\ ${ }^{*}$ Corresponding Author: Scott M. Belcher, smbelch2@ncsu.edu \\ Telephone: 919-513-1214
}

Keywords: gestation, epigenetic, essential metals, metallothionein, placenta

Running header: Gestational Cd exposure disrupts offspring essential metals 


\begin{abstract}
In CD-1 mice, gestational-only exposure to cadmium (Cd) causes female-specific hepatic insulin resistance, metabolic disruption, and obesity. To evaluate whether sex differences in cadmium uptake and changes in essential metal concentrations contribute to metabolic outcomes, placental and liver cadmium and essential metal concentrations were quantified in male and female offspring perinatally exposed to $500 \mathrm{ppb} \mathrm{CdCl}_{2}$. Exposure resulted in increased maternal liver $\mathrm{Cd}^{+2}$ concentrations $(364 \mu \mathrm{g} / \mathrm{kg}$ ) similar to concentrations found in non-occupationally exposed human liver. At gestational day (GD) 18, placental cadmium and manganese concentrations were significantly increased in exposed males and females, and zinc was significantly decreased in females. Placental efficiency was significantly decreased in GD18 exposed males. Increases in hepatic $\mathrm{Cd}$ concentrations and a transient prenatal increase in zinc were observed in exposed female liver. Fetal and adult liver iron concentrations were decreased in both sexes, and decreases in hepatic zinc, iron, and manganese were observed in exposed females. Analysis of GD18 placental and liver metallothionein mRNA expression revealed significant Cd-induced upregulation of placental metallothionein in both sexes, and a significant decrease in fetal hepatic metallothionein in exposed females. In placenta, expression of metal ion transporters responsible for metal ion uptake was increased in exposed females. In liver of exposed adult female offspring, expression of the divalent cation importer (S/c39a14/Zip14) decreased, whereas expression of the primary exporter (S/c30a10) increased. These findings demonstrate that Cd can preferentially cross the female placenta, accumulate in the liver, and cause lifelong dysregulation of metal ion concentrations associated with metabolic disruption.
\end{abstract}




\section{Introduction}

Cadmium $(\mathrm{Cd})$ is a ubiquitous environmental contaminant ranked $7^{\text {th }}$ on the list of toxicants of concern by the Agency for Toxic Substances and Disease Registry (ATSDR 2012 Sep). In human adults, elevated $\mathrm{Cd}$ exposure increases risk of cardiovascular disease, hypertension, diabetes, osteoporosis, impaired kidney function, and cancer (Tellez-Plaza et al. 2013; Åkesson et al. 2014). Emerging data suggests developmental Cd exposure increases risk for childhood obesity (King et al. 2015; Lamas et al. 2016). Using a mouse model of human gestational Cd exposure, we previously demonstrated that $\mathrm{Cd}$ body burdens equivalent to women of childbearing age sex-specifically caused hepatic steatosis, dyslipidemia, glucose intolerance, insulin resistance, and obesity in female offspring (Jackson et al. 2020). The resulting later-in-life obesogenic effects of gestational Cd exposure in females were found to be mediated by wellestablished mechanisms involved in cumulative Cd toxicity (Sabolić et al. 2010; Nair et al. 2013; Nemmiche 2016 Nov 1). Specifically, oxidative stress, endoplasmic reticulum stress, and mitochondrial dysfunction were notable at birth in exposed female offspring and progressed to pathologic metabolic disease without continued Cd exposure. The resulting severe liver damage and obesity were linked with female-specific developmental disruption of hepatic retinoic acid signaling, programing of hepatic toxicity, disrupted insulin signaling, metabolic dysregulation leading to obesity, and an increase biomarkers of hepatocellular carcinoma (Jackson et al. 2020).

In apparent contrast to our findings that brief developmental Cd exposures caused adverse metabolic impacts later in life, $\mathrm{Cd}$ is generally considered a cumulative toxicant, meaning that toxic effects develop over time as Cd accumulates due to slow elimination (Waalkes 2003; Jacobo-Estrada et al. 2017). Previous studies examining circulating maternal Cd transfer to the fetus found that $\mathrm{Cd}$ is largely sequestered in placenta, resulting in little or no fetal $\mathrm{Cd}$ accumulation (Mikolić et al. 2015). However, those conclusions are from studies that compared placental Cd concentrations to $\mathrm{Cd}$ in whole fetus, an approach that underestimates $\mathrm{Cd}$ sequestered in target tissues such as fetal liver (Sigel et al. 2013; Mikolić et al. 2015). Further, impacts of relatively low 
concentrations of $\mathrm{Cd}$, differences in $\mathrm{Cd}$ exposure in male and female fetus, and impacts of fetal sex as a modifier of placental ability to sequester Cd are not well studied.

Cadmium accumulates primarily in liver and kidney, with much lower levels accumulating in pancreas, heart, testis, bone, and neural tissues (ATSDR 2012 Sep). Organ-specific patterns of Cd uptake and toxicity are mediated by differential expression of SLC39 transporters, SLC30 transporters, and divalent metal transporter-1 (DMT1) (Fujishiro et al. 2012). The functional roles of Zip8 (SLC39A8) and Zip14 (SLC39A14) Zinc (Zn) and Manganese (Mn) transporter proteins in regulating absorption, intracellular uptake, accumulation, and toxicity of $\mathrm{Cd}$ in testis, kidney, and liver are well established (Sabolić et al. 2010; Fujishiro et al. 2012; Aydemir and Cousins 2018; Fujishiro and Himeno 2019). The physiological role of divalent metal ion transporters is to regulate essential divalent metal ion homeostasis, a regulatory process adversely impacted by $\mathrm{Cd}$ (Aydemir and Cousins 2018). In addition to $\mathrm{Zn}$ and Cd ion transport, Zip14 also functions as the liver's Mn transporter, which works with Mn efflux transporter Slc30a10 (ZnT10) to regulate $\mathrm{Mn}$ homeostasis in various tissues including liver (Mercadante et al. 2019: 10).

The placenta is a critical regulator of offspring health that coordinates fetal nutrition and oxygen transfer, and responds to $\mathrm{Cd}$ exposure by sequestering $\mathrm{Cd}$ and upregulating expression of metallothionein (Lau et al. 1998; Everson et al. 2019). During pregnancy, Zip14, Slc39a4 (Zip4), DMT1, and Slc30a2 (ZnT2) facilitate uptake and transfer of essential metals and Cd from maternal blood vessels to placenta, and subsequent transfer from placenta to fetal cord blood (Espart et al. 2018). There is ample evidence demonstrating that $\mathrm{Cd}$ alters homeostasis of $\mathrm{Zn}$, Fe, and $\mathrm{Mn}$ (Moulis 2010). For example, adult Cd exposure induces anemia by altering iron metabolism and homeostasis, whereas increased pregnancy and lactation Cd levels associated with Fe deficiency (Akesson et al. 2002; Horiguchi et al. 2011). We also observed anemia at birth in newborn mice following maternal exposure to $500 \mathrm{ppb} \mathrm{CdCl}_{2}$, a find that suggests iron concentrations were altered by gestational exposure to relatively low Cd concentrations (Jackson et al. 2020). 
Considering the important roles of metallothioneins and metal ion transporters in $\mathrm{Cd}$ toxicity and essential metal homeostasis, we hypothesized that gestational Cd exposure alters placental metallothionein and dysregulates $\mathrm{Zn}$ transporter expression in female placenta and Cd accumulation in female fetal livers. Further, increases of $\mathrm{Cd}$ in female offspring liver would result in lifelong changes in metallothionein and hepatic transporter expression, and dysregulated adult hepatic divalent cation concentrations. To evaluate these hypotheses, inductively coupled plasma mass spectrometry was used to quantify concentrations of $\mathrm{Cd}^{2+}, \mathrm{Fe}^{2+}, \mathrm{Mn}^{2+}$ and $\mathrm{Zn}^{2+}$ in maternal livers, placenta, and offspring livers following perinatal exposure of pregnant dams to $500 \mathrm{ppb}$ $\mathrm{CdCl}_{2}$ in drinking water. Impacts of exposure on transcription of genes involved in metal ion homeostasis, and epigenetic regulation of those genes, were evaluated. Analyses included samples collected from gestational day (GD)18 through postnatal day (PND)120 to describe progression of metal homeostasis disruption and evaluate differences in hepatic $\mathrm{Cd}$ concentrations in male and female offspring following gestational Cd exposure.

\section{Materials and Methods}

\subsection{Animal Husbandry}

All animal procedures were carried out as previously described (Jackson et al. 2020) following recommendations of the Panel on Euthanasia of the American Veterinary Medical Association, and were approved by the North Carolina State University Institutional Animal Care and Use Committee. Study animals were housed in single-use polyethylene cages (Innovive, San Diego, CA) with Sanichip bedding (PJ Murphy Forest Products Corp, Montville, NJ) and pulped virgin cotton fiber nestlets (Ancare, Bellmore, NY) on a $12: 12$ light cycle at $25^{\circ} \mathrm{C}$ and $45 \%-60 \%$ average relative humidity in an AAALAC accredited animal facility. Defined AIN-93G diet (D10012G; lot: 17010510A6, Research Diets, New Brunswick, NJ) and sterile drinking water produced from a reverse osmosis water purification system (Millipore Rios with ELIX UV/Progard 2, Billerica, MA) was supplied ad libitum. Strain CRL:CD-1(ICR) ;CD-1) male and female breeder 
mice were obtained from Charles River Laboratories (Raleigh, NC) and assigned a randomized identification number. Beginning 2 weeks prior to mating and ending on postnatal day 10 (PND10), drinking water of dams in the Cd-exposed group was supplemented with a final concentration of $0.5 \mu \mathrm{g} / \mathrm{L}$ (500 ppb) cadmium chloride $\left(\mathrm{CdCl}_{2}\right.$; CAS 10108-64-2; 99.99\% purity, Lot MKBM1769V, Sigma Aldrich). Beginning on PND10, drinking water for both control and exposed study groups for the remainder of the study was Cd-free.

A subset of dams ( $\mathrm{n}=3$ per group) was euthanized by $\mathrm{CO}_{2}$ asphyxiation and rapid decapitation at GD18 and fetuses isolated by dissection. Those procedures were completed 2-3 hours after lights on. Dams and fetuses were weighed, and tissues were collected. The intrauterine position of each fetus was recorded and fetal genetic sex was determined by Sryspecific PCR as previously described (Lambert et al. 2000). For the remaining litters, litter size, pup sex, and pup weight were recorded on the day following parturition (PND1). Offspring were separated from dams at PND21 and housed 2-4 per cage separated by sex and study group. From each litter, one male and one female representative of the mean litter body weight was euthanized at PND1, PND21, PND42, PND90, and at study termination on PND120. Study animals remained in their home cage, with food and water available, until euthanized by carbon dioxide asphyxiation or transcardiac perfusion under isoflurane anesthesia.

All study animals were necropsied with study samples and tissues isolated at the time of sacrifice. Systematic bias was avoided by housing animals randomly on cage racks and ensuring the timing and order of measurements, data collection, and experimental manipulations were the same. Necropsy was performed at the same approximate time of day, independent of study group, and dependent on date of birth. For adult females, analysis and sample collection were performed in estrus. All manipulations, tissue collections, and analysis were done by investigators blinded to study group.

\subsection{Tissue Isolation and ICP-MS}


At necropsy, tissues were dissected, frozen on powdered dry ice, and stored at $-80^{\circ} \mathrm{C}$ until prepared for analysis. Samples were digested in $1 \mathrm{~mL}$ trace metal grade nitric acid (Thermo Fisher, Waltham, MA; Catalog \#A509) and $1 \mathrm{~mL}$ hydrogen peroxide (Thermo Fisher, Waltham, MA; Catalog \#H341) at $100{ }^{\circ} \mathrm{C}$ for 3 hours. Digested samples were allowed to cool and filtered through a $0.22-\mu \mathrm{m}$ filter (Millipore Sigma, Burlington, MA; Catalog \#SLMP025SS). The filtered solution was transferred to a $50 \mathrm{~mL}$ conical tube, internal standards were added, samples were then adjusted to a final volume of $50 \mathrm{~mL}$ with deionized water and vortexed for 30 seconds. Identically prepared samples lacking added tissue were used as procedural blanks. Tissue metal concentrations determined using an ICAP RQ ICP-MS (Thermo Fisher, Waltham, MA) at the NCSU Molecular Education, Technology and Research Innovation Center. Bovine liver standard (SRM 1577c) was purchased from the National Institute of Science and Technology. The accuracy and precision of our analysis for tissue cadmium, zinc, iron, and manganese levels were assessed with a standard reference bovine liver () in each analysis. Certified values for the metals in the reference bovine liver were $97 \mu \mathrm{g} / \mathrm{kg}$ for $\mathrm{Cd}$ and 181, 198, and $10.5 \mu \mathrm{g} / \mathrm{g}$ dry-tissue weight for $\mathrm{Zn}, \mathrm{Fe}$, and Mn, respectively. Observed mean values SRM 1577c ( $\mathrm{n}=17$ ) of $98 \mu \mathrm{g} / \mathrm{kg}$ for Cd and 189, and 206, and $13 \mu \mathrm{g} / \mathrm{g}$ dry-tissue weight for $\mathrm{Zn}$, Fe, and Mn, respectively. The coefficient of variation was $7.0 \%$ for $\mathrm{Cd}, 12.1 \%$ for $\mathrm{Zn}, 13.3 \%$ for $\mathrm{Fe}$, and $13.8 \%$ for $\mathrm{Mn}$. Limits of detection (LOD) were $0.1 \mathrm{ppb}$ for each analyte. Values below the detection limit were replaced by interpolated values calculated by dividing the LOD by the square root of 2 (Sanford et al. 1993).

\subsection{Quantitative RT-PCR analysis}

Total RNA was isolated using the RNEasy Mini Kit (Qiagen, Valencia, CA). One $\mu$ g of RNA was reverse transcribed using the high-capacity cDNA reverse transcription kit (Applied Biosystems; Grand Island, NY) following manufacturer's protocols. Standard PCR amplification was performed in triplicate on a Step One Plus Real-Time PCR System (Applied Biosystems; Grand Island, NY) in a final volume of $20 \mu \mathrm{L}$ containing $\sim 10 \mathrm{ng}$ of cDNA (1.5 $\mu \mathrm{L}$ of RT product), 1x Universal Master Mix and TaqMan expression assay primers (Supplemental Table 1); Applied 
Biosystems; Grand Island, NY). Relative expression was quantified using the $2^{\Delta \Delta C t}$ method, in which $\Delta \Delta \mathrm{Ct}$ is the normalized value.

\subsection{Analysis of DNA methylation in putative promoter regions}

Bisulfite pyrosequencing assays were developed to quantitatively measure the level of methylation at $\mathrm{CpG}$ sites within putative promoter regions upstream of the metal ion transporters Slc30a10 and Slc39a14. Genomic DNA $(1 \mu \mathrm{g})$ was treated with sodium bisulfite using the EZ DNA Methylation Gold Kit per manufacturer's instructions (Zymo Research; Irvina, CA). Bisulfite converted DNA ( $20 \mathrm{ng}$ ) was amplified by PCR in a $25 \mu \mathrm{l}$ reaction volume using HotStartTaq plus DNA polymerase (Qiagen; Germantown, MD) with $1.5 \mathrm{mM} \mathrm{MgCl} 2$ and $0.12 \mu \mathrm{M}$ each of the forward and reverse primer (Supplemental Table 2), and $2.5 \mu$ of CoralLoad Concentrate (Qiagen). The reverse primer of each pair was biotin conjugated at the 5' end, with single stranded amplicons isolated on the Pyrosequencing Work Station and pyrosequencing was performed on a Pyromark Q96 MD instrument (Qiagen; Germantown, MD). Pyrosequencing assays were performed in duplicate, and values reported as the mean methylation of $\mathrm{CpG}$ sites contained within the sequence analyzed. Using those methods, a minimum $5 \%$ difference in methylation can be detected (Murphy et al. 2012).

\subsection{Data and Statistical Analysis}

All procedures, measurements and endpoint assessments were made by investagators blinded to treatments, litter, and sex when appropriate. To avoid influence of extreme litter size on endpoint sensitivity, litters with fewer than 6 pups were excluded from analysis and litters with greater than 14 pups were culled to a maximum of 12 (Palmer and Ulbrich 1997). Analysis of body weight, placenta weight, and placental efficiency, data were analyzed using two-way ANOVA (sex, exposure), with litter size included as a covariate. Trace metal concentration data were analyzed using a two-way ANOVA (sex, exposure) for each metal at each timepoint with litter size and litter included as covariates. If overall effects were significant, a Tukey's least significant differences post hoc test was performed to evaluate pair-wise differences. Effect sizes 
were calculated depending on the statistical test, values for " $\eta^{2}$ " for ANOVA, "Cohen's d" for ttests, and "r" for Mann-Whitney U are reported. Significance between differences in values were defined as $p<.05$. All data was analyzed using Prism ${ }^{\circledR}$ v9 (GraphPad; La Jolla, California) and SPSS V.26 (IBM, California). A table of all statistical analyses and results for morphometrics and metal concentrations is included in Supplemental Table 3.

\section{Results}

\subsection{Effects of gestational Cd exposure on body weight and placental efficiency}

Placenta weight of Cd-exposed males was increased $18 \%$ from $0.11 \pm 0.17$ to $0.13 \pm 0.39$ grams $(p=.02 ;$ Figure $1 A)$ and placental efficiency was decreased $14 \%$ from $14 \pm 2$ to $12 \pm 4(p$ $=.04 ;$ Figure 1B). Placenta weight and placental efficiency were unchanged in Cd-exposed females.

\subsection{Prenatal metal content in liver and placenta}

At GD18, maternal Cd-exposure resulted in increased concentrations in mean female and male placental $\mathrm{Cd}(\mathrm{p}<.0001$; Figure 1C; Table 1). Offspring liver $\mathrm{Cd}$ concentrations were significantly increased in exposed females $(p<.0001)$ but not male $(p=.34$; Figure $1 \mathrm{D} ;$ Table 1$)$. Pregnant female liver $\mathrm{Cd}$ concentrations were also significantly increased by exposure $(p=.003$; Figure 1E; Table 1). Concentrations of $\mathrm{Zn}$ in the placenta of female offspring were significantly decreased $(p<.0001)$ whereas Mn concentrations were increased $(p=.03)$. In exposed male placenta mean Mn concentrations were increased by exposure $(p=.005)$, however there was no change in $\mathrm{Zn}$ concentrations $(p=.78)$. Placental iron concentrations were not changed by $\mathrm{Cd}$ exposure in either sex (Table 1).

Essential metal concentrations in male livers at GD18 were unchanged in the maternal Cd exposure group (Table 1). Concentrations of $\mathrm{Zn}$ in livers of exposed females at GD18 were significantly increased $(p<.0001)$ whereas hepatic Fe concentrations were decreased $(p=.01)$ Manganese concentrations of female fetal livers were not changed by maternal Cd exposure. 
Hepatic Cd concentrations in exposed female offspring were positively associated with hepatic Zn $(p=.003)$ and placental Cd $(p=.046)$ concentrations, but negatively correlated with placental Zn $(p=.001)$. Hepatic Zn levels were positively correlated with placental Cd $(p=.001)$ and negatively correlated with placental $\mathrm{Zn}$ in exposed female offspring $(p<.0001$; Figure 2A). Liver Fe in liver of exposed male offspring was negatively correlated with placental $\mathrm{Mn}(p=.05)$, and placental Cd was positively correlated with placental $\mathrm{Mn}(p=.001$; Figure 2B).

\subsection{Postnatal Liver Metal Concentrations}

In the postnatal liver of exposed female offspring, Cd concentrations at PND21 were significantly increased and remained elevated at each adult time point analyzed (Table 2). Liver cadmium concentrations in unexposed adult male offspring were below the limit of detection (LOD $=0.1 \mu \mathrm{g} / \mathrm{kg}$ ), with only a modest increase in liver Cd detectable in exposed males (Table 2).

Zinc concentrations in exposed female liver significantly decreased beginning at PND21 $(p=.0009)$ and remained decreased at each adult time point (Table 2; Figure 3A). By contrast, Zn concentrations in exposed male liver were not significantly changed at each time point analyzed (Table 2; Figure 3B). Compared to control females, hepatic Fe of exposed females was decreased throughout life, and during adulthood Fe levels were significantly decreased at each adult time point (Table 2; Figure 3C). In exposed male liver, significant decreases in liver iron concentrations were also observed, with significant decreases observed at PND90 and PND120 (Table 2; Figure 3D). Manganese concentrations were decrease in exposed female livers throughout postnatal life, whereas liver $\mathrm{Mn}$ in males was unchanged (Table 2; Figure 3E,3F).

\subsection{Gestational Cd mediated changes in metallothionein and metal transporter gene expression}

Quantitative RT-PCR was performed on hepatic and placental mRNA to evaluate the progression of dysregulation of mRNA expression of genes involved in metal homeostasis (Table 3 and 4). At GD18, expression of Mt1 and Mt2 were increased by Cd exposure in both placenta and liver. In exposed placenta, Mt1 was $4.8 \pm 1.07$-fold upregulated in females $(p<.0001)$ and $2.0 \pm 0.64$-fold upregulated in males $(p=.04)$. Expression of Mt2 was significantly increased $(p$ 
$<.0001$ ) only in female placenta (Table 3). Placental mRNA expression of Slc39a14 was upregulated in females $(p<.0001)$ but not males $(p=.19$; Table 3$)$. Transcripts encoding the two transporters primarily responsible for efflux of divalent metal cations from the placenta into the cord blood (Dmt1 and ZnT2; Figure 4) were both increased in placenta of Cd exposed females and males (Dmt1: females: $p<.0001$; males: $p=.16$. ZnT2: females: $p=.004 ;$ males: $p=.39$; Table 3).

\subsection{Postnatal changes in metallothionein and metal transporter gene expression}

Because hepatic and metabolic pathology was observed only in Cd-exposed females, analysis of postnatal changes in mRNA expression of genes encoding metal ion transporters and metallothionein was limited to female offspring. At PND1, gestational Cd exposure increased Slc39a4 $(p=.04)$ and decreases Slc39a6 $(p=.004)$ mRNA expression (Table 3). Expression of mRNA zinc transporter associated with mitochondrial defects, S/c25a16, was significantly decreased at PND1, decreased expression was observed at all time points (Table 3 and Table 4). Expression of mRNA encoding the primary Zn influx (Slc39a14, Zip14) or efflux (Slc30a10, ZnT10) transporters were not significantly changed at PND1. At PND21 and PND42 mRNA expression of S/c39a14 was significantly decreased and S/c30a10 expression was significantly (Table 3 and Table 4). At PND42, significant changes in expression of 11 of the 28 metal ion transporter genes analyzed were observed (Table 4). Expression of 4 of 17 influx transporters (e.g., Slc39 family) were significantly decreased, while expression of mRNA encoding 3 transporters was increased (Table 4). At PND42 mRNA expression of primary efflux transporters S/c30a6 and S/c30a10 were significantly increased, and Slc30a9 was decreased by gestational Cd exposure. Significant decreases in expression of metallothionein $(M t 1, M t 3)$ were also observed at PND42 (Table 4).

\subsection{Promotor DNA methylation analysis}

In females gestationally exposed to $\mathrm{Cd}$, there were no differences in the methylation levels at $\mathrm{CpG}$ sites within putative promoter regions upstream of the gene encoding Slc30a10 (Control: 
$1.6 \pm 0.88 \% ; \mathrm{CdCl}_{2}: 1.3 \pm 0.93 \% ; p=.42$ ), Slc25a16 (Control: $0.60 \pm 0.35 \% ; \mathrm{CdCl}_{2}: 0.48 \pm 0.40$ $\% ; p=.53$ ), Slc39a6 (Control: $0.78 \pm 0.42 \% ; \mathrm{CdCl}_{2}: 0.45 \pm 0.29 \% ; p=.09$ ), or Slc39a14 (Control: $1.13 \pm 1.26 \% ; \mathrm{CdCl}_{2}: 2.06 \pm 1.58 \% ; p=.21 ;$ Supplemental Table 4). All four of the putative promoter regions upstream of genes encoding metal ion transporters are fully unmethylated. Promoter regions upstream of the gene encoding Mt1, the CpG sites were all approximately $25 \%$ methylated with no differences detected between control and Cd-exposed groups (Control: $24 \pm$ $17 \% ; \mathrm{CdCl}_{2}: 26 \pm 15 \% ; \mathrm{p}=.79 ;$ Supplemental Table 4).

\section{Discussion}

The primary study findings were that sex-specific adverse metabolic effects of gestational Cd exposure observed previously were associated with increased transplacental Cd transfer from dam to female offspring, with subsequent $\mathrm{Cd}$ accumulation in female liver. It is considered probable that $\mathrm{Cd}$ accumulation is programming female offspring for hepatic dysfunction, resulting in the adverse metabolic disruption observed in adult females (Jackson et al. 2020). In our previous study we demonstrated that maternal blood Cd levels of exposed dams at mating was similar to geometric mean blood $\mathrm{Cd}$ concentrations for women of childbearing age in the US. Additional evidence for human relevance of this mouse model was demonstrated here with the finding of mean maternal liver concentrations of the Cd-exposed group (364 $\pm 99 \mathrm{ug} / \mathrm{kg})$ was comparable to nonoccupationally human population in the US (ATSDR 2012 Sep). Overall, our findings that female-specific gestational uptake of $\mathrm{Cd}$ by the fetus results in severe metabolic pathology later-in-life and indicates that even small, short-term exposures to $\mathrm{Cd}$ during development are harmful and likely a considered significant threat to human metabolic health. As is recognized for lead exposure, there may be no safe level of $\mathrm{Cd}$ exposure during development.

\subsection{Cd accumulates in male and female placenta and decreases efficiency of male placenta}

In our previous study, compared to unexposed controls, Cd exposure resulted in a small but significant $5.5 \%$ increase in the female GD18 fetus weight, whereas male fetus weight was 
unchanged (Jackson et al. 2020). Here, exposed male, but not female GD18 placenta weight was increased by $22 \%$ leading to a $15 \%$ decline in placental efficiency. Placental efficiency is a proxy measure for placental function and metabolic rate and quantified as the ratio of fetal to placental weight, reflecting grams of fetus produced per grams placenta (Hayward et al. 2016). Observed increases in placenta weight suggest male-specific placental compensatory mechanisms are occurring in response to Cd that warrant additional study. In mammals, Cd was previously demonstrated to poorly cross the placenta; however, previous analyses have not accounted for offspring sex and analyzed Cd concentrations in whole fetal homogenates, thereby limiting sensitivity to detect Cd accumulation (Mikolić et al. 2015). By contrast, here we observed significant Cd levels in GD18 female fetal livers that were 5 times greater than background levels found in males. Placental Cd levels were similarly elevated in both males and females, with mean total $\mathrm{Cd}$ of $7.1 \mathrm{ng}$ in females and $7.5 \mathrm{ng}$ in males, which is consistent with previous findings that material Cd accumulates in placenta. In adult offspring, significant $\mathrm{Cd}$ was detected only in female offspring liver. Those findings suggest Cd preferentially crosses female placenta in CD-1 mice and accumulates in liver. The retention of $\mathrm{Cd}$ in adult liver is consistent with the longer elimination half-life of Cd in females (Taguchi and Suzuki 1981; Satarug et al. 2010). It is probable that Cd accumulated in both placenta and livers of female offspring is exerting direct toxic effects contributing to the sex-specific metabolic disease and obesity in adulthood.

\subsection{Gestational Cd alters essential metal levels}

In addition to previously demonstrated Cd-induced decreases in hemoglobin levels, we observed that $\mathrm{Cd}$ exposure significantly decreased fetal and adult liver Fe and placental $\mathrm{Zn}$ concentrations and increased placental $\mathrm{Mn}$ in both sexes. These findings are consistent with evidence from human birth cohort studies showing $\mathrm{Cd}$ exposures are associated anemia, iron and zinc deficiencies (Akesson et al. 2002; Horiguchi et al. 2011; Ikeh-Tawari et al. 2013; Vidal et al. 2015; Luo et al. 2017). Along with anemia, maternal Zn deficiency is associated with fetal 
death, congenital malformations, intrauterine growth retardation, reduced birth weight, and other adverse health outcomes (Chaffee and King 2012). In rodent models, maternal Zn deficiency can also induce insulin resistance in adult offspring, even with adequate adult $\mathrm{Zn}$ (Jou et al. 2010). In the context of those results, placental $\mathrm{Zn}$ deficiencies in $\mathrm{Cd}$ exposed females may play a programing role in the etiology of $\mathrm{Cd}$-induced adult female metabolic disease.

Along with placental metal concentration changes, sex-specific disruption of essential metal concentrations was evident in GD18 livers. Specifically, Fe was decreased $15 \%$ in male liver, and $\mathrm{Zn}$ increased $26 \%$ in female liver, suggesting differences in compensatory responses to Cd. Impacts were persistent with decreased hepatic Zn, Fe, and Mn levels in Cd exposed adult females, and a significant decrease in Fe in adult males. In females, placenta and liver Cd levels positively correlate with liver Zn, and are negatively correlated with placental Zn, providing further evidence that placental $\mathrm{Cd}$ influences female essential metal concentrations. The persistent changes in female divalent cation levels suggest gestational $\mathrm{Cd}$ is programming lifelong alterations in hepatic essential metal homeostasis.

\subsection{Dysregulation of hepatic and placental metal ion transporters and metallothionein}

Members of SLC39 and SLC30 family transporters, DMT1, and metallothionein are important regulators of essential metal homeostasis and play critical roles in Cd toxicity. Expression of these transporters is tissue-specifically responsive to $\mathrm{Fe}, \mathrm{Zn}$, and $\mathrm{Cd}$ (DufnerBeattie et al. 2003; Taylor et al. 2005; Aydemir and Cousins 2018). However, effects of "low-dose" developmental or chronic Cd exposure on later-in-life expression in metabolically relevant tissues is unknown. Zinc and $\mathrm{Cd}$ arrive in placenta from maternal blood via divalent cation transporters and are then delivered to cord blood and fetus primarily via ZnT2, Zip14, and Dmt1 (Espart et al. 2018). During pregnancy, Cd is transported to cord blood through placental DMT1, causing downregulation of $\mathrm{Zn}$ transporters, reduced $\mathrm{Zn}$ transport to the fetus, resulting in fetal $\mathrm{Zn}$ deficiency (Espart et al. 2018). We observed upregulation of Slc39a14, which encodes the Zip14 Zn transporter responsible for uptake from maternal blood vessels into the placenta, ZnT2, and 
Dmt1 in Cd exposed female placentas, which likely explains female-specific increased hepatic Cd and $\mathrm{Zn}$ at GD18 (Figure 4).

In Cd-exposed females, expression of 12 of 28 analyzed metal ion transporter genes were modified in adult liver, including primary influx transporter, S/c39a14, and primary efflux transporter, S/c30a10. Additionally, gestational Cd exposure downregulated expression of metal transporters at PND1, PND21, and PND42 including Slc39a4 (Zip4), and Slc25a16 (Jackson et al. 2020). Zip4 encodes a tissue-specific, zinc-regulated zinc transporter in mice inversely responsive to dietary Zn levels (Dufner-Beattie et al. 2003). Heterozygous Zip4-knockout mice display varied phenotypes including severe growth retardation exacerbated by maternal $\mathrm{Zn}$ deficiency and ameliorated by maternal $\mathrm{Zn}$ supplementation (Dufner-Beattie et al. 2007). Slc25a16 is associated with mitochondrial defects and reduction in mitochondrial coenzyme A levels (Prohl et al. 2001; Gutiérrez-Aguilar and Baines 2013). Based on observed effects, gestational $\mathrm{Cd}$ appears to act as a $\mathrm{Zn}$ mimic, inducing a long-term epigenetic alteration in metal transporter expression that persists into adulthood and contributes to fatty liver disease and insulin insensitivity pathogenesis.

Gestational Cd exposure also altered expression of placental and liver metallothionein mRNA. The metal-binding metallothioneins are involved in regulation of absorption, transport, and homeostasis of essential trace metals, and have cytoprotective functions binding and sequestering toxic metals including Cd (Palmiter 1987; Andrews 1990; Dalton et al. 1994; Klaassen et al. 2009; Sabolić et al. 2010). In vivo and in vitro experimental studies demonstrated Cd-induced changes in metal ion transporter and metallothionein expression are involved in the mechanisms of Cd-induced toxicity and dysregulation of $\mathrm{Zn}$ homeostasis (Akesson et al. 2002; Sabolić et al. 2010; Thévenod 2010; Horiguchi et al. 2011; Genchi et al. 2020). Cumulative Cd toxicity results from high-affinity binding of $\mathrm{Cd}^{2+}$ by metallothionein and a resulting dosedependent loss of protective antioxidant mechanisms leading to oxidative damage (Sabolić et al. 2010; Nair et al. 2013; Nemmiche 2016 Nov 1). Metallothionein expression is induced by 
increased free $\mathrm{Zn}^{2+}$ levels via metal-response element binding transcription factor 1 (Radtke et al. 1993: 1; Andrews 2001: 1; Bhandari et al. 2017) and by free $\mathrm{Cd}^{2+}$ indirectly through release of metallothionein-bound $\mathrm{Zn}^{2+}$ (Kägi and Schäffer 1988; Klaassen et al. 2009). Cadmium-induced alterations in metallothionein expression contribute to disruptions of essential metal homeostasis. Both major metallothionein isoforms, $M t 1$ and $M t 2$, were upregulated in placenta of Cd exposed females, consistent with previous work demonstrating placental induction of metallothionein in rats gestationally exposed to Cd (Nakamura et al. 2012). In males, only Mt1 mRNA expression was significantly upregulated. Paradoxically, hepatic metallothionein was downregulated at GD18 and PND42 in females, further indicating disrupted metal sensing is a more complex interplay during gestation than free metal ions directly induing metallothionein production. This is supported by studies in transgenic mice overexpressing MT1 that accumulate $\mathrm{Zn}$ in maternal compartments and are resistant to teratogenic effects of Zn deficiency during pregnancy, whereas Mt1 knockout mice accumulate less $\mathrm{Zn}$ in maternal tissues and are susceptible to teratogenic effects of dietary Zn deficiency (Dalton et al. 1996; Dalton et al. 1997; Bittel et al. 1998; Andrews and Geiser 1999). The observed metallothionein downregulation may contribute to decreased $\mathrm{Zn}$ accumulation in female liver and adverse metabolic impacts resulting from gestational Cd exposure in females.

\subsection{Gestational Cd did not alter CpG methylation of transporter or metallothionein promoters}

Due to early and persistent disruption of mRNA expression of metal ion transporters and metallothionein, gestational Cd seemingly causes lifelong epigenetic expression changes. However, differences in CpG DNA methylation within putative promoter regions upstream of Zip14, ZnT10, Zip6, Slc25a16, or the primary hepatic metallothionein Mt1 were not observed. The CpG island in metal ion transporter promoters were essentially unmethylated and unchanged by Cd exposure. Epigenetic modifications are one type of mechanism representing an organismal response to environmental stressors, yet regions of the epigenome responsive to Cd or other trace metals are largely unknown (Heijmans et al. 2009). Because both MT isoforms are similarly responsive to induction by $\mathrm{Cd}$ exposure, the two genes likely share common promoter elements 
(Andersen et al. 1983; Searle et al. 1984). Demethylation of DNA sequences in the vicinity of the MT1 gene correlates with upregulation of mRNA expression (Compere and Palmiter 1981). In the promoter region upstream of the mouse Mt1 gene, no differences were detected in CPG methylation at any CpG site examined. Because CpG methylation upstream of genes encoding metal ion transporters and metallothionein were unchanged, transcriptional epigenetic regulation appears not to involve promoter proximal regulation of $\mathrm{CpG}$ methylation. Considering the absence of changes in DNA methylation, the notable Cd deposition specifically in female livers may itself be the mechanistic drive of gestational Cd-induced adult disease. Early accumulation of $\mathrm{Cd}$ in female livers may directly program adult disease via developmental toxicity that alters lifelong metabolic function. This interpretation is consistent with lifelong changes in metallothionein and metal ion transporter mRNA expression leading to decreased hepatic $\mathrm{Zn}, \mathrm{Fe}$, and $\mathrm{Mn}$ in adult females.

\section{Conclusion}

Maternal exposure to $500 \mathrm{ppb} \mathrm{CdCl}_{2}$ in mice disrupted essential metal concentrations in female offspring. To the best of our knowledge, the finding of detectable Cd levels in female fetal and adult livers following gestational Cd exposure is the first report of an important sex difference in maternal-fetal transfer of $\mathrm{Cd}$. The observed sex-specific fetal transfer and long retention of $\mathrm{Cd}$ in female livers was linked to adverse decreases in hepatic $\mathrm{Zn}$ concentrations and altered metal ion transporter and metallothionein mRNA expression. These findings suggest gestational $\mathrm{Cd}$ accumulation is programming adult metabolic disease through altered essential metal homeostasis.

Funding: This work was supported in part by NIEHS training grant 5T32ES007046-38 and NIEHS award P30ES025128.

Conflicts: The authors declare no conflicts of interest. 
Figure Legends:

Figure 1: Effects of gestational $\mathrm{CdCl} 2$ exposure on placental efficiency and tissue cadmium levels. At GD18, placentas of female fetuses were unaffected by exposure to gestational $\mathrm{CdCl}$, whereas male placenta weights were increased (A). Placental efficiency is shown as fetal weight divided by placental weight, where female offspring show no effect of gestational $\mathrm{CdCl} 2$ exposure and male placental efficiency is reduced $(\mathrm{B})$. Cadmium concentration of tissues were quantified using ICP-MS. In the placenta of offspring exposed to $\mathrm{CdCl} 2$ during gestation, both sexes showed accumulation with an average in females of 62 $\mu \mathrm{g} / \mathrm{kg}$ and in males of $53 \mu \mathrm{g} / \mathrm{kg}(\mathrm{C})$. Offspring liver concentrations of $\mathrm{Cd}$ are shown plotted against age (D). In offspring female livers at GD18 following gestational exposure to $\mathrm{CdCl}$, a significant accumulation of Cadmium was noted with an average of $29 \mu \mathrm{g} / \mathrm{kg}$, whereas males did not have a significantly elevated accumulation of Cd with an average of $5.6 \mu \mathrm{g} / \mathrm{kg}$. An average of $22 \mu \mathrm{g} / \mathrm{kg} \mathrm{Cd}$ was detected in females gestationally exposed to $\mathrm{CdCl} 2$ in livers at PND21, $21 \mu \mathrm{g} / \mathrm{kg}$ Cd in livers at PND42, $18 \mu \mathrm{g} / \mathrm{kg}$ Cd in livers at PND90 and $17 \mu \mathrm{g} / \mathrm{kg}$ Cd in livers at PND120. An average of $3.8 \mu \mathrm{g} / \mathrm{kg} \mathrm{Cd}$ was detected in males gestationally exposed to $\mathrm{CdCl} 2$ in livers at PND42, $0.05 \mu \mathrm{g} / \mathrm{kg}$ Cd in livers at PND90, and $2.3 \mu \mathrm{g} / \mathrm{kg} \mathrm{Cd}$ in livers at PND120. In livers isolated from dams exposed to $\mathrm{CdCl} 2$ at GD18 of their pregnancy, an average of $364 \mu \mathrm{g} / \mathrm{kg}$ Cadmium was detected $(\mathrm{E})$. Placenta weight and efficiency: Females: control, n=17; $\mathrm{CdCl} 2, \mathrm{n}=14$. Males: control, $\mathrm{n}=20 ; \mathrm{CdCl}$, n=22. Cadmium levels: GD18: Females: control, $n=9 ; \mathrm{CdCl} 2, \mathrm{n}=11$. Males: control, $n=8 ; \mathrm{CdCl} 2, \mathrm{n}=10$. PND21: Females: control, $n=4 ; \mathrm{CdCl} 2, \mathrm{n}=4$. PND42: Females: control, $\mathrm{n}=5 ; \mathrm{CdCl} 2, \mathrm{n}=4$. Males: control, $\mathrm{n}=4$, $\mathrm{CdCl}$, n=4. PND90: Females: control, n=6; $\mathrm{CdCl} 2, \mathrm{n}=4$. Males: control, $\mathrm{n}=4$; $\mathrm{CdCl}$, $\mathrm{n}=6$. PND120: Females: control, $n=5, \mathrm{CdCl}$, n=4. Males: Control, $n=3 ; \mathrm{CdCl}, \mathrm{n}=5$. Dams: control, $\mathrm{n}=3 ; \mathrm{CdCl} 2, \mathrm{n}=3$. Samples were collected from 3 litters per treatment. All values shown are mean $\pm S D$. The level of statistical significance for differences between mean values of control and $\mathrm{CdCl}$-exposed groups was determined by a two-way ANOVA (treatment, sex) with a 
Tukey's post hoc test for all experiments and is indicated by * $(p<0.05)$. Litter was included as a covariate.

Figure 2: Correlation matrix of metal concentration in offspring CD-1 mouse liver and placenta at GD18. A Pearson Correlation Matrix of liver and placental metal concentration is shown for females (A) and males (B). In females, hepatic cadmium has a significant positive correlation with hepatic zinc and placental $\mathrm{Cd}$, and a significant negative correlation with placental zinc. Hepatic zinc was positively correlated with placental Cd and negatively correlated with placental Zn. In males, hepatic iron was negatively correlated with placental manganese, and placental $\mathrm{Cd}$ was positively correlated with placental manganese. Liver: Females: control, $n=9 ; \mathrm{CdCl} 2, \mathrm{n}=11$. Males: control, $\mathrm{n}=8 ; \mathrm{CdCl} 2, \mathrm{n}=10$. Placenta: Females: control, $n=10 ; \mathrm{CdCl} 2, \mathrm{n}=11$. Males: control, $n=10 ; \mathrm{CdCl} 2, \mathrm{n}=12$. All samples come from three unique litters per treatment.

Figure 3. Effects of gestational exposure to $\mathrm{CdCl}_{2}$ on essential metal concentration in offspring CD-1 mice liver. Liver concentration of the essential metals Zinc (A, B), Iron (C, D), and Manganese $(E, F)$ are shown for offspring female $(A, C, E)$ and male $(B, D, F)$ livers isolated and flash frozen at GD18, PND21, PND42, PND90, and PND120. In females, hepatic zinc at GD18 was increased from 211 in controls to $266 \mu \mathrm{g} / \mathrm{g}$ in Cd-exposed offspring, at PND21 was decreased from 153 to $119 \mu \mathrm{g} / \mathrm{g}$ in Cd-exposed offspring, at PND42 was decreased from 141 to $116 \mu \mathrm{g} / \mathrm{g}$ in Cd-exposed offspring, at PND90 was decreased from 166 to $90 \mu \mathrm{g} / \mathrm{g}$ in Cdexposed offspring, and at PND120 was decreased from 149 to $91 \mu \mathrm{g} / \mathrm{g}$ in Cd-exposed offspring. In females, hepatic iron at GD18 was decreased from 291 to $271 \mu \mathrm{g} / \mathrm{g}$ in Cd-exposed offspring, at PND21 was unchanged, at PND42 was decreased from 284 to $186 \mu \mathrm{g} / \mathrm{g}$ in Cd-exposed offspring, at PND90 was decreased from 326 to $230 \mu \mathrm{g} / \mathrm{g}$ in Cd-exposed offspring, and at PND120 was decreased from 299 to $190 \mu \mathrm{g} / \mathrm{g}$ in Cd-exposed offspring. In females, hepatic manganese was unchanged at GD18, decreased from 4.7 to $3.9 \mu \mathrm{g} / \mathrm{g}$ in Cd-exposed offspring at PND21, decreased from 5.2 to $3.3 \mu \mathrm{g} / \mathrm{g}$ in Cd-exposed offspring at PND42, decreased from 
4.8 to $3.7 \mu \mathrm{g} / \mathrm{g}$ in Cd-exposed offspring at PND90, and decreased from 4.6 to $3.5 \mu \mathrm{g} / \mathrm{g}$ in Cdexposed offspring at PND120. In males, no changes were detected in essential metals at GD18 or PND42. In males at PND90 and PND120, the only changes noted in males were decreases in hepatic iron from 324 to $256 \mu \mathrm{g} / \mathrm{g}$ in Cd-exposed offspring at PND90 and from 352 to 288 $\mu \mathrm{g} / \mathrm{g}$ in Cd-exposed offspring at PND120. GD18 Females: control, $\mathrm{n}=9$; $\mathrm{CdCl}$, $\mathrm{n}=11$. Males: control, $\mathrm{n}=8$; $\mathrm{CdCl}$, $\mathrm{n}=10$. PND21 Females: control, $\mathrm{n}=4$; $\mathrm{CdCl}$, $\mathrm{n}=4$. PND42 Females: control, $\mathrm{n}=5 ; \mathrm{CdCl} 2, \mathrm{n}=4$. Males: control, $\mathrm{n}=4 ; \mathrm{CdCl} 2, \mathrm{n}=4$. PND90 Females: control, $\mathrm{n}=6 ; \mathrm{CdCl}, \mathrm{n}=4$. Males: control, $n=4 ; \mathrm{CdCl}$, n=6. PND120 Females: control, $n=5 ; \mathrm{CdCl}$, $n=4$. Males: control, $\mathrm{n}=4 ; \mathrm{CdCl} 2, \mathrm{n}=5$. The level of statistical significance for differences between mean values of control and $\mathrm{CdCl}$-exposed groups was determined by a two-way ANOVA (treatment, sex) with a Tukey's post hoc test for all experiments and is indicated by * $(p<0.05)$. All images show mean \pm SD.

Figure 4. Graphic Representation of Gestational Cd Disruption Placental and Hepatic Metal Concentration and Alters mRNA Expression of Metal Ion Transporters. This graphic illustrates that dams were exposed to $500 \mathrm{ppb} \mathrm{CdCl}_{2}$ in drinking water. Exposed dams accumulated 850X more Cd than control dams by GD18. At GD18, 15X more Cd was detected in the placenta and $\sim 8 \mathrm{X}$ more $\mathrm{Cd}$ in the liver of exposed female offspring than control female offspring. Gestational Cd exposure resulted in decreased placental Zn and increased placental $\mathrm{Mn}$ in exposed female offspring. Metallothionein mRNA expression was upregulated in exposed female placenta. The transporter responsible for uptake from maternal blood vessels into the placenta (ZIP14) and the transporters responsible for uptake from the placenta into the fetal cord blood (DMT1, ZnT2) were upregulated in the placentas of exposed female offspring relative to same-sex controls. In fetal livers from $\mathrm{Cd}$-exposed animals, $\mathrm{Cd}$ and $\mathrm{Zn}$ concentration were increased, whereas metallothionein levels were downregulated and remained downregulated into adulthood. The increased hepatic $Z n$ was transient. Metal ion transporters responsible for influx of divalent metal cations into the liver were significantly downregulated in 
adulthood, whereas efflux transporters responsible for export into the bile were significantly upregulated. By adulthood, the hepatic Zn phenotypes reversed, with adult hepatic Zn decreases in exposed female offspring. 


\section{References}

Åkesson A, Barregard L, Bergdahl IA, Nordberg GF, Nordberg M, Skerfving S. 2014. Non-renal effects and the risk assessment of environmental cadmium exposure. Environ Health Perspect. 122(5):431-438. doi:10.1289/ehp.1307110.

Akesson A, Berglund M, Schütz A, Bjellerup P, Bremme K, Vahter M. 2002. Cadmium exposure in pregnancy and lactation in relation to iron status. Am J Public Health. 92(2):284-287. doi:10.2105/ajph.92.2.284.

Andersen RD, Birren BW, Ganz T, Piletz JE, Herschman HR. 1983. Molecular cloning of the rat metallothionein 1 (MT-1) mRNA sequence. DNA Mary Ann Liebert Inc. 2(1):15-22.

doi:10.1089/dna.1.1983.2.15.

Andrews GK. 1990. Regulation of metallothionein gene expression. Prog Food Nutr Sci. 14(23):193-258.

Andrews GK. 2001. Cellular zinc sensors: MTF-1 regulation of gene expression. Biometals Int J Role Met lons Biol Biochem Med. 14(3-4):223-237. doi:10.1023/a:1012932712483.

Andrews GK, Geiser J. 1999. Expression of the mouse metallothionein-I and -II genes provides a reproductive advantage during maternal dietary zinc deficiency. J Nutr. 129(9):1643-1648. doi:10.1093/jn/129.9.1643.

ATSDR. 2012 Sep. Agency for Toxic Substances and Disease Registry. Toxicological Profile for Cadmium. Dep Health Hum Serv Public Health Serv.

Aydemir TB, Cousins RJ. 2018. The Multiple Faces of the Metal Transporter ZIP14 (SLC39A14). J Nutr. 148(2):174-184. doi:10.1093/jn/nxx041.

Bhandari S, Melchiorre C, Dostie K, Laukens D, Devisscher L, Louwrier A, Thees A, Lynes MA. 2017. Detection and Manipulation of the Stress Response Protein Metallothionein. Curr Protoc Toxicol. 71:17.19.1-17.19.28. doi:10.1002/cptx.17.

Bittel D, Dalton T, Samson SL, Gedamu L, Andrews GK. 1998. The DNA binding activity of metal response element-binding transcription factor-1 is activated in vivo and in vitro by zinc, but not by other transition metals. J Biol Chem. 273(12):7127-7133. doi:10.1074/jbc.273.12.7127.

Chaffee BW, King JC. 2012. Effect of zinc supplementation on pregnancy and infant outcomes: a systematic review. Paediatr Perinat Epidemiol. 26 Suppl 1:118-137. doi:10.1111/j.13653016.2012.01289.x.

Compere SJ, Palmiter RD. 1981. DNA methylation controls the inducibility of the mouse metallothionein-I gene lymphoid cells. Cell. 25(1):233-240. doi:10.1016/0092-8674(81)90248-8.

Dalton T, Fu K, Palmiter RD, Andrews GK. 1996. Transgenic mice that overexpress metallothionein-I resist dietary zinc deficiency. J Nutr. 126(4):825-833. doi:10.1093/jn/126.4.825.

Dalton T, Palmiter RD, Andrews GK. 1994. Transcriptional induction of the mouse metallothionein-I gene in hydrogen peroxide-treated Hepa cells involves a composite major late 
transcription factor/antioxidant response element and metal response promoter elements. Nucleic Acids Res. 22(23):5016-5023. doi:10.1093/nar/22.23.5016.

Dalton TP, Bittel D, Andrews GK. 1997. Reversible activation of mouse metal response element-binding transcription factor 1 DNA binding involves zinc interaction with the zinc finger domain. Mol Cell Biol. 17(5):2781-2789. doi:10.1128/mcb.17.5.2781.

Dufner-Beattie J, Wang F, Kuo Y-M, Gitschier J, Eide D, Andrews GK. 2003. The Acrodermatitis Enteropathica Gene ZIP4 Encodes a Tissue-specific, Zinc-regulated Zinc Transporter in Mice. J Biol Chem. 278(35):33474-33481. doi:10.1074/jbc.M305000200.

Dufner-Beattie J, Weaver BP, Geiser J, Bilgen M, Larson M, Xu W, Andrews GK. 2007. The mouse acrodermatitis enteropathica gene Slc39a4 (Zip4) is essential for early development and heterozygosity causes hypersensitivity to zinc deficiency. Hum Mol Genet. 16(12):1391-1399. doi:10.1093/hmg/ddm088.

Espart A, Artime S, Tort-Nasarre G, Yara-Varón E. 2018. Cadmium exposure during pregnancy and lactation: materno-fetal and newborn repercussions of $\mathrm{Cd}(\mathrm{ii})$, and $\mathrm{Cd}$-metallothionein complexes. Met Integr Biometal Sci. 10(10):1359-1367. doi:10.1039/c8mt00174j.

Everson TM, Marable C, Deyssenroth MA, Punshon T, Jackson BP, Lambertini L, Karagas MR, Chen J, Marsit CJ. 2019. Placental Expression of Imprinted Genes, Overall and in Sex-Specific Patterns, Associated with Placental Cadmium Concentrations and Birth Size. Environ Health Perspect. 127(5):57005. doi:10.1289/EHP4264.

Fujishiro H, Himeno S. 2019. New Insights into the Roles of ZIP8, a Cadmium and Manganese Transporter, and Its Relation to Human Diseases. Biol Pharm Bull. 42(7):1076-1082. doi:10.1248/bpb.b18-00637.

Fujishiro H, Yano Y, Takada Y, Tanihara M, Himeno S. 2012. Roles of ZIP8, ZIP14, and DMT1 in transport of cadmium and manganese in mouse kidney proximal tubule cells. Met Integr Biometal Sci. 4(7):700-708. doi:10.1039/c2mt20024d.

Genchi G, Sinicropi MS, Lauria G, Carocci A, Catalano A. 2020. The Effects of Cadmium Toxicity. Int J Environ Res Public Health. 17(11):E3782. doi:10.3390/ijerph17113782.

Gutiérrez-Aguilar M, Baines CP. 2013. Physiological and pathological roles of mitochondrial SLC25 carriers. Biochem J. 454(3):371-386. doi:10.1042/BJ20121753.

Hayward CE, Lean S, Sibley CP, Jones RL, Wareing M, Greenwood SL, Dilworth MR. 2016. Placental Adaptation: What Can We Learn from Birthweight:Placental Weight Ratio? Front Physiol. 7:28. doi:10.3389/fphys.2016.00028.

Heijmans BT, Tobi EW, Lumey LH, Slagboom PE. 2009. The epigenome: archive of the prenatal environment. Epigenetics. 4(8):526-531. doi:10.4161/epi.4.8.10265.

Horiguchi H, Oguma E, Kayama F. 2011. Cadmium induces anemia through interdependent progress of hemolysis, body iron accumulation, and insufficient erythropoietin production in rats. Toxicol Sci Off J Soc Toxicol. 122(1):198-210. doi:10.1093/toxsci/kfr100. 
Ikeh-Tawari EP, Anetor JI, Charles-Davies MA. 2013. Cadmium level in pregnancy, influence on neonatal birth weight and possible amelioration by some essential trace elements. Toxicol Int. 20(1):108-112. doi:10.4103/0971-6580.111558.

Jackson T, Ryherd G, Scheibly C, Sasser A, Guillette T, Belcher S. 2020. Gestational Cd Exposure in the CD-1 Mouse Induces Sex-specific Hepatic Insulin Insensitivity, Obesity, and Metabolic Syndrome in Adult Female Offspring. Toxicol Sci.

Jacobo-Estrada T, Santoyo-Sánchez M, Thévenod F, Barbier O. 2017. Cadmium Handling, Toxicity and Molecular Targets Involved during Pregnancy: Lessons from Experimental Models. Int J Mol Sci. 18(7). doi:10.3390/ijms18071590.

Jou M-Y, Philipps AF, Lönnerdal B. 2010. Maternal zinc deficiency in rats affects growth and glucose metabolism in the offspring by inducing insulin resistance postnatally. J Nutr. 140(9):1621-1627. doi:10.3945/jn.109.119677.

Kägi JH, Schäffer A. 1988. Biochemistry of metallothionein. Biochemistry. 27(23):8509-8515. doi:10.1021/bi00423a001.

King KE, Darrah TH, Money E, Meentemeyer R, Maguire RL, Nye MD, Michener L, Murtha AP, Jirtle R, Murphy SK, et al. 2015. Geographic clustering of elevated blood heavy metal levels in pregnant women. BMC Public Health. 15:1035. doi:10.1186/s12889-015-2379-9.

Klaassen CD, Liu J, Diwan BA. 2009. Metallothionein protection of cadmium toxicity. Toxicol Appl Pharmacol. 238(3):215-220. doi:10.1016/j.taap.2009.03.026.

Lamas GA, Navas-Acien A, Mark DB, Lee KL. 2016. Heavy Metals, Cardiovascular Disease, and the Unexpected Benefits of Chelation Therapy. J Am Coll Cardiol. 67(20):2411-2418. doi:10.1016/j.jacc.2016.02.066.

Lambert JF, Benoit BO, Colvin GA, Carlson J, Delville Y, Quesenberry PJ. 2000. Quick sex determination of mouse fetuses. J Neurosci Methods. 95(2):127-132. doi:10.1016/s01650270(99)00157-0.

Lau JC, Joseph MG, Cherian MG. 1998. Role of placental metallothionein in maternal to fetal transfer of cadmium in genetically altered mice. Toxicology. 127(1):167-178. doi:10.1016/S0300-483X(98)00028-6.

Luo Y, McCullough LE, Tzeng J-Y, Darrah T, Vengosh A, Maguire RL, Maity A, Samuel-Hodge C, Murphy SK, Mendez MA, et al. 2017. Maternal blood cadmium, lead and arsenic levels, nutrient combinations, and offspring birthweight. BMC Public Health. 17(1):354. doi:10.1186/s12889-017-4225-8.

Mercadante CJ, Prajapati M, Conboy HL, Dash ME, Herrera C, Pettiglio MA, Cintron-Rivera L, Salesky MA, Rao DB, Bartnikas TB. 2019. Manganese transporter Slc30a10 controls physiological manganese excretion and toxicity. J Clin Invest. 129(12):5442-5461. doi:10.1172/JCl129710.

Mikolić A, Piasek M, Sulimanec Grgec A, Varnai VM, Stasenko S, Kralik Oguić S. 2015. Oral cadmium exposure during rat pregnancy: assessment of transplacental micronutrient transport and steroidogenesis at term. J Appl Toxicol JAT. 35(5):508-519. doi:10.1002/jat.3055. 
Moulis J-M. 2010. Cellular mechanisms of cadmium toxicity related to the homeostasis of essential metals. Biometals Int J Role Met lons Biol Biochem Med. 23(5):877-896. doi:10.1007/s10534-010-9336-y.

Murphy SK, Huang Z, Hoyo C. 2012. Differentially Methylated Regions of Imprinted Genes in Prenatal, Perinatal and Postnatal Human Tissues. PLoS ONE. 7(7). doi:10.1371/journal.pone.0040924. [accessed 2020 Apr 13]. https://www.ncbi.nlm.nih.gov/pmc/articles/PMC3396645/.

Nair AR, DeGheselle O, Smeets K, Van Kerkhove E, Cuypers A. 2013. Cadmium-Induced Pathologies: Where Is the Oxidative Balance Lost (or Not)? Int J Mol Sci. 14(3):6116-6143. doi:10.3390/ijms14036116.

Nakamura Y, Ohba K-I, Ohta H. 2012. Participation of metal transporters in cadmium transport from mother rat to fetus. J Toxicol Sci. 37(5):1035-1044. doi:10.2131/jts.37.1035.

Nemmiche S. 2016 Nov 1. Oxidative Signaling Response to Cadmium Exposure. Toxicol Sci.:kfw222. doi:10.1093/toxsci/kfw222.

Palmer AK, Ulbrich BC. 1997. The cult of culling. Fundam Appl Toxicol Off J Soc Toxicol. 38(1):7-22. doi:10.1006/faat.1997.2319.

Palmiter RD. 1987. Molecular biology of metallothionein gene expression. Experientia Suppl. 52:63-80. doi:10.1007/978-3-0348-6784-9_4.

Prohl C, Pelzer W, Diekert K, Kmita H, Bedekovics T, Kispal G, Lill R. 2001. The yeast mitochondrial carrier Leu5p and its human homologue Graves' disease protein are required for accumulation of coenzyme A in the matrix. Mol Cell Biol. 21(4):1089-1097. doi:10.1128/MCB.21.4.1089-1097.2001.

Radtke F, Heuchel R, Georgiev O, Hergersberg M, Gariglio M, Dembic Z, Schaffner W. 1993. Cloned transcription factor MTF-1 activates the mouse metallothionein I promoter. EMBO J. 12(4):1355-1362.

Sabolić I, Breljak D, Skarica M, Herak-Kramberger CM. 2010. Role of metallothionein in cadmium traffic and toxicity in kidneys and other mammalian organs. Biometals Int J Role Met Ions Biol Biochem Med. 23(5):897-926. doi:10.1007/s10534-010-9351-z.

Sanford RF, Pierson CT, Crovelli RA. 1993. An objective replacement method for censored geochemical data. Math Geol. 25(1):59-80. doi:10.1007/BF00890676.

Satarug S, Garrett SH, Sens MA, Sens DA. 2010. Cadmium, environmental exposure, and health outcomes. Environ Health Perspect. 118(2):182-190. doi:10.1289/ehp.0901234.

Searle PF, Davison BL, Stuart GW, Wilkie TM, Norstedt G, Palmiter RD. 1984. Regulation, linkage, and sequence of mouse metallothionein I and II genes. Mol Cell Biol. 4(7):1221-1230. doi:10.1128/mcb.4.7.1221-1230.1984.

Sigel A, Sigel H, Sigel RKO, editors. 2013. Cadmium: from toxicity to essentiality. Dordrecht ; New York: Springer (Metal ions in life sciences). 
Taguchi T, Suzuki S. 1981. Influence of sex and age on the biological half-life of cadmium in mice. J Toxicol Environ Health. 7(2):239-249. doi:10.1080/15287398109529975.

Taylor KM, Morgan HE, Johnson A, Nicholson RI. 2005. Structure-function analysis of a novel member of the LIV-1 subfamily of zinc transporters, ZIP14. FEBS Lett. 579(2):427-432. doi:10.1016/j.febslet.2004.12.006.

Tellez-Plaza M, Jones MR, Dominguez-Lucas A, Guallar E, Navas-Acien A. 2013. Cadmium exposure and clinical cardiovascular disease: a systematic review. Curr Atheroscler Rep. 15(10):356. doi:10.1007/s11883-013-0356-2.

Thévenod F. 2010. Catch me if you can! Novel aspects of cadmium transport in mammalian cells. Biometals Int J Role Met Ions Biol Biochem Med. 23(5):857-875. doi:10.1007/s10534010-9309-1.

Vidal AC, Semenova V, Darrah T, Vengosh A, Huang Z, King K, Nye MD, Fry R, Skaar D, Maguire R, et al. 2015. Maternal cadmium, iron and zinc levels, DNA methylation and birth weight. BMC Pharmacol Toxicol. 16:20. doi:10.1186/s40360-015-0020-2.

Waalkes MP. 2003. Cadmium carcinogenesis. Mutat Res. 533(1-2):107-120. doi:10.1016/j.mrfmmm.2003.07.011. 
Table 1. Metal content of dam liver and offspring liver and placenta at GD18 measured by ICP-MS

\begin{tabular}{|c|c|c|c|c|c|c|c|c|c|c|}
\hline & \multirow{2}{*}{\multicolumn{2}{|c|}{ Dam }} & \multicolumn{4}{|c|}{ Placenta } & \multicolumn{4}{|c|}{ Liver } \\
\hline & & & \multicolumn{2}{|c|}{ Female } & \multicolumn{2}{|c|}{ Male } & \multicolumn{2}{|c|}{ Female } & \multicolumn{2}{|c|}{ Male } \\
\hline & Control & $\mathrm{CdCl}_{2}$ & Control & $\mathrm{CdCl}_{2}$ & Control & $\mathrm{CdCl}_{2}$ & Control & $\mathrm{CdCl}_{2}$ & Control & $\mathrm{CdCl}_{2}$ \\
\hline $\begin{array}{l}\text { Cadmium } \\
(\mu \mathrm{g} / \mathrm{kg})\end{array}$ & $0.43 \pm 0.27$ & $364 \pm 99^{*}$ & $4.1 \pm 4.9$ & $62 \pm 41$ & $2.5 \pm 2.5$ & $53 \pm 23$ & $3.7 \pm 3.2$ & $29 \pm 12$ & $2.0 \pm 1.9$ & $5.5 \pm 6.1$ \\
\hline $\begin{array}{l}\text { Zinc } \\
(\mu \mathrm{g} / \mathrm{g})\end{array}$ & $155 \pm 4.5$ & $150 \pm 5.9$ & $157 \pm 11$ & $101 \pm 10$ & $160 \pm 11$ & $158 \pm 8.6$ & $211 \pm 17$ & $266 \pm 25$ & $190 \pm 11$ & $185 \pm 22$ \\
\hline $\begin{array}{c}\text { Iron } \\
(\mu \mathrm{g} / \mathrm{g})\end{array}$ & $307 \pm 28$ & $302 \pm 8.7$ & $132 \pm 13$ & $127 \pm 13$ & $137 \pm 26$ & $135 \pm 12$ & $291 \pm 24$ & $271 \pm 24$ & $311 \pm 52$ & $264 \pm 41$ \\
\hline $\begin{array}{c}\text { Manganese } \\
(\mu \mathrm{g} / \mathrm{g})\end{array}$ & $4.4 \pm 0.13$ & $4.4 \pm 0.78$ & $2.4 \pm 0.43$ & $3.1 \pm 0.87$ & $2.5 \pm 0.46$ & $3.3 \pm 0.72$ & $6.3 \pm 1.6$ & $6.6 \pm 1.7$ & $5.4 \pm 0.86$ & $5.6 \pm 1.1$ \\
\hline
\end{tabular}

Values represent group mean $\pm S D ;$ Bold ${ }^{*}$ indicates significant difference; $p<.05$. CdCl2 = 500ppb gestational Cadmium Chloride. Below LOD were defined as LOD/sqrt(2). Dam: $n=3 /$ group. Placenta: females: control $n=10, C d C l 2 n=11$; males: control $n=10, C d C / 2 n=12$. Fetal liver: females: control $n=9$, CdCl2 $n=11$; males: control $n=8, C d C / 2 n=10$. 
bioRxiv preprint doi: https://doi.org/10.1101/2021.11.06.46755.1; this version posted November 7, 2021. The copyright holder for this preprint

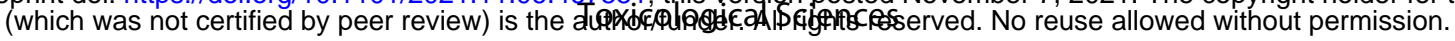

1

2

3

4

5

6

7

8

9

10

11

12

13

14

15

16

17

18

19

20

21

22

23

24

25

26

27

28

29

30

31

32

33

34

35

36

37

38

39

40

41

42

43

44

45

46

47

48

49

50

51

52

53

54

55

56

57

58

59

60

Table 2. Metal content of offspring liver measured by ICP-MS

\begin{tabular}{|c|c|c|c|c|c|c|c|c|c|c|c|c|c|c|}
\hline & \multirow{2}{*}{\multicolumn{2}{|c|}{$\begin{array}{l}\text { PND21 } \\
\text { Female } \\
\end{array}$}} & \multicolumn{4}{|c|}{ PND42 } & \multicolumn{4}{|c|}{ PND90 } & \multicolumn{4}{|c|}{ PND120 } \\
\hline & & & \multicolumn{2}{|c|}{ Female } & \multicolumn{2}{|c|}{ Male } & \multicolumn{2}{|c|}{ Female } & \multicolumn{2}{|c|}{ Male } & \multicolumn{2}{|c|}{ Female } & \multicolumn{2}{|c|}{ Male } \\
\hline & Control & $\mathrm{CdCl}_{2}$ & Control & $\mathrm{CdCl}_{2}$ & Control & $\mathrm{CdCl}_{2}$ & Control & $\mathrm{CdCl}_{2}$ & Control & $\mathrm{CdCl}_{2}$ & Control & $\mathrm{CdCl}_{2}$ & Control & $\mathrm{CdCl}_{2}$ \\
\hline $\begin{array}{c}\text { Cadmium } \\
(\mu \mathrm{g} / \mathrm{kg})\end{array}$ & $0.07 \pm 0$ & $22 \pm 4$ & $.68 \pm .91$ & $21 \pm 5.0$ & $0.07 \pm 0$ & $3.8 \pm 5.2$ & $0.10 \pm .08$ & $18 \pm 7.8$ & $0.07 \pm 0$ & $0.10 \pm 0.05$ & $0.12 \pm .13$ & $17 \pm 5.6$ & $0.07 \pm 0$ & $2.3 \pm 2.9$ \\
\hline $\begin{array}{c}\text { Zinc } \\
(\mu \mathrm{g} / \mathrm{g})\end{array}$ & $153 \pm 6.9$ & $119 \pm 8.7$ & $141 \pm 11$ & $116 \pm 6.1$ & $133 \pm 12$ & $130 \pm 18$ & $166 \pm 14$ & $90 \pm 8.7$ & $159 \pm 34$ & $133 \pm 19$ & $149 \pm 13$ & $91 \pm 8.8$ & $143 \pm 19$ & $126 \pm 19$ \\
\hline $\begin{array}{c}\text { Iron } \\
(\mu \mathrm{g} / \mathrm{g})\end{array}$ & $366 \pm 11$ & $331 \pm 29$ & $284 \pm 9.1$ & $186 \pm 10$ & $294 \pm 13$ & $279 \pm 23$ & $326 \pm 31$ & $230 \pm 41$ & $324 \pm 34$ & $256 \pm 31$ & $299 \pm 42$ & $190 \pm 24$ & $352 \pm 61$ & $288 \pm 27$ \\
\hline $\begin{array}{c}\text { Manganese } \\
(\mu \mathrm{g} / \mathrm{g})\end{array}$ & $4.7 \pm 0.49$ & $3.9 \pm 0.21$ & $5.2 \pm 0.60$ & $3.3 \pm 0.22$ & $4.4 \pm 0.27$ & $4.5 \pm 0.84$ & $4.8 \pm 0.55$ & $3.7 \pm 0.55$ & $5.3 \pm 0.48$ & $4.8 \pm 0.62$ & $4.6 \pm 0.32$ & $3.5 \pm 0.23$ & $5.1 \pm 0.12$ & $4.5 \pm 0.98$ \\
\hline
\end{tabular}

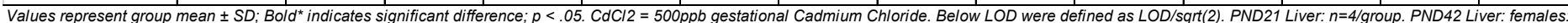

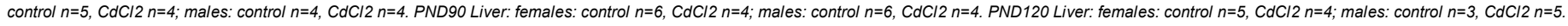


bioRxiv preprint doi: https://doi.org/10.1101/2021.11.06.467551; this version posted November 7, 2021. The copyright holder for this preprin

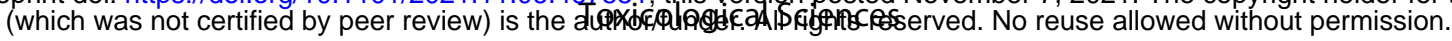

Table 3. qRT-PCR Results for mRNA Expression Changes in Placenta and Developing Liver

\begin{tabular}{|c|c|c|c|c|c|c|c|c|c|c|}
\hline \multicolumn{3}{|c|}{ GD18 Placenta } & \multicolumn{4}{|l|}{ Female } & \multicolumn{4}{|l|}{ Male } \\
\hline Gene & Test statistic & P-value & Fold Change (Mean \pm SD) & $\begin{array}{c}\text { Sample size } \\
\text { (control, } \mathrm{CdCl}_{2} \text { ) }\end{array}$ & $\begin{array}{c}\text { Directio } \\
\mathrm{n}\end{array}$ & P-value & $\begin{array}{c}\text { Fold Change (Mean } \\
\pm \text { SD) }\end{array}$ & $\begin{array}{c}\text { Sample size } \\
\text { (control, } \mathrm{CdCl}_{2} \text { ) }\end{array}$ & \begin{tabular}{|c|} 
Directio \\
$\mathrm{n}$
\end{tabular} & P-value \\
\hline SIc11a2 & $F(1,18)=20.7$ & .0002 & $3.76 \pm 1.04$ & 6,6 & $\uparrow$ & $<.0001$ & $1.86 \pm 1.22$ & 4,6 & - & .16 \\
\hline SIc30a2 & $F(1,18)=2.5$ & .01 & $2.2 \pm 0.71$ & 6,6 & $\uparrow$ & .004 & $1.35 \pm 0.68$ & 4,6 & - & .39 \\
\hline Slc30a10 & $F(1,17)=1.8$ & .19 & $0.59 \pm 0.56$ & 6,5 & - & - & $0.78 \pm 0.55$ & 4,6 & - & - \\
\hline Slc39a4 & $F(1,18)=4.6$ & .046 & $2.33 \pm 1.06$ & 6,6 & - & .007 & $1.08 \pm 0.66$ & 4,6 & - & .87 \\
\hline Slc39a8 & $F(1,18)=3.6$ & .07 & $1.54 \pm 0.41$ & 6,6 & - & - & $1.15 \pm 0.26$ & 4,6 & - & - \\
\hline SIc39a14 & $F(1,18)=19.4$ & .0003 & $2.72 \pm 0.76$ & 6,6 & $\uparrow$ & $<.0001$ & $1.52 \pm 0.59$ & 4,6 & - & .19 \\
\hline Mt1 & $F(1,17)=48.7$ & $<.0001$ & $4.78 \pm 1.07$ & 6,6 & $\uparrow$ & $<.0001$ & $1.95 \pm 0.64$ & 4,6 & $\uparrow$ & 0.04 \\
\hline Mt2 & $F(1,18)=28.9$ & $<.0001$ & $2.72 \pm 0.53$ & 6,6 & $\uparrow$ & $<.0001$ & $1.34 \pm 0.59$ & 4,6 & - & .25 \\
\hline Mt3 & ND & ND & ND & 6,6 & - & ND & ND & 4,6 & - & ND \\
\hline \multicolumn{3}{|l|}{ GD18 Liver } & \multicolumn{4}{|l|}{ Female } & \multicolumn{4}{|l|}{ Male } \\
\hline Gene & Test statistic & P-value & Fold Change (Mean \pm SD) & $\begin{array}{c}\text { Sample size } \\
\text { (control, } \mathrm{CdCl}_{2} \text { ) }\end{array}$ & $\begin{array}{c}\text { Directio } \\
\mathrm{n}\end{array}$ & P-value & $\begin{array}{c}\text { Fold Change (Mean } \\
\pm S D)\end{array}$ & $\begin{array}{c}\text { Sample size } \\
\text { (control, } \mathrm{CdCl}_{2} \text { ) }\end{array}$ & \begin{tabular}{|c|} 
Directio \\
$\mathrm{n}$
\end{tabular} & P-value \\
\hline Mt1 & $F(1,19)=36.2$ & $<.0001$ & $0.34 \pm 0.1$ & 6,7 & $\downarrow$ & $<.0001$ & $0.82 \pm 0.23$ & 4,6 & - & .11 \\
\hline Mt2 & $F(1,19)=1.2$ & .29 & $0.81 \pm 0.28$ & 6,7 & - & - & $0.93 \pm 0.26$ & 4,6 & - & - \\
\hline Mt3 & ND & ND & ND & 6,7 & - & ND & ND & 4,6 & - & ND \\
\hline \multicolumn{6}{|c|}{ PND1 Female Liver } & \multicolumn{5}{|c|}{ PND21 Female Liver } \\
\hline Gene & Test statistic & $\begin{array}{l}\text { Fold Change } \\
(\text { Mean } \pm \text { SD) }\end{array}$ & $\begin{array}{l}\text { Sample size (control, } \\
\left.\mathrm{CdCl}_{2}\right)\end{array}$ & Direction & P-value & Test statistic & $\begin{array}{c}\text { Fold Change (Mean } \\
\pm \text { SD) }\end{array}$ & $\begin{array}{c}\text { Sample size } \\
\text { (control, } \mathrm{CdCl}_{2} \text { ) }\end{array}$ & \begin{tabular}{|c|} 
Directio \\
$\mathrm{n}$
\end{tabular} & P-value \\
\hline Slc11a2 & $\mathrm{t}(1,6)=0.84$ & $0.90 \pm 0.17$ & 4,4 & - & .43 & $t(1,4)=1.41$ & $1.40 \pm 0.47$ & 3,3 & - & .23 \\
\hline SIc25a16 & $t(1,6)=3.0$ & $1.43 \pm 0.24$ & 4,4 & $\uparrow$ & .02 & $t(1,4)=5.6$ & $1.78 \pm 0.24$ & 3,3 & - & .005 \\
\hline Slc30a10 & $t(1,6)=1.7$ & $0.75 \pm 0.22$ & 4,4 & - & .14 & $t(1,4)=3.1$ & $2.04 \pm 0.57$ & 3,3 & $\uparrow$ & .04 \\
\hline Slc39a4 & $t(1,6)=2.8$ & $1.8 \pm 0.47$ & 4,4 & $\uparrow$ & .04 & $t(1,4)=3.0$ & $1.87 \pm 0.28$ & 3,3 & - & .04 \\
\hline Slc39a6 & $t(1,6)=4.5$ & $0.81 \pm 0.08$ & 4,4 & $\downarrow$ & .004 & $t(1,4)=1.4$ & $0.72 \pm 0.22$ & 3,3 & - & .24 \\
\hline Slc39a8 & $t(1,6)=0.39$ & $0.97 \pm 0.04$ & 4,4 & - & .39 & $t(1,4)=0.12$ & $0.97 \pm 0.31$ & 3,3 & - & .91 \\
\hline Slc39a14 & $t(1,6)=0.78$ & $1.09 \pm 0.10$ & 4,4 & - & .47 & $t(1,4)=4.3$ & $0.68 \pm 0.05$ & 3,3 & $\downarrow$ & .01 \\
\hline
\end{tabular}


Table 4. qRT-PCR Results of mRNA Expression Changes in Adult Female Liver

\begin{tabular}{|c|c|c|c|c|c|}
\hline \multirow[b]{2}{*}{ Gene } & \multicolumn{5}{|c|}{ PND42 Female Liver } \\
\hline & Test statistic & Fold Change (Mean \pm SD) & $\begin{array}{c}\text { Sample } \\
\text { size } \\
(\text { control, } \\
\mathrm{CdCl}_{2} \text { ) }\end{array}$ & Direction & P-value \\
\hline Slc11a1 & $t(1,4)=1.5$ & $1.25 \pm 0.17$ & 3,3 & - & .27 \\
\hline Slc11a2 & $t(1,4)=2.1$ & $1.3 \pm 0.14$ & 3,3 & - & .17 \\
\hline Slc25a16 & $t(1,4)=4.9$ & $0.73 \pm 0.13$ & 3,3 & $\downarrow$ & .02 \\
\hline Slc30a1 & $t(1,4)=0.40$ & $1.05 \pm 0.12$ & 3,3 & - & .73 \\
\hline Slc30a2 & $t(1,4)=2.2$ & $0.92 \pm 0.04$ & 3,3 & - & .27 \\
\hline Slc30a3 & $t(1,4)=2.2$ & $1.6 \pm 0.27$ & 3,3 & - & .15 \\
\hline Slc30a4 & $t(1,4)=1.1$ & $1.13 \pm 0.11$ & 3,3 & - & .37 \\
\hline Slc30a5 & $t(1,4)=1.3$ & $0.84 \pm 0.12$ & 3,3 & - & .32 \\
\hline SIc30a6 & $t(1,4)=3.2$ & $1.37 \pm 0.12$ & 3,3 & $\uparrow$ & .04 \\
\hline Slc30a7 & $t(1,4)=1.1$ & $0.89 \pm 0.10$ & 3,3 & - & .39 \\
\hline Slc30a8 & $t(1,4)=2.2$ & $1.25 \pm 0.11$ & 3,3 & - & .16 \\
\hline Slc30a9 & $t(1,4)=4.5$ & $0.88 \pm 0.03$ & 3,3 & $\downarrow$ & .045 \\
\hline Slc30a10 & $t(1,4)=1.8$ & $2.35 \pm 0.19$ & 3,3 & $\uparrow$ & .009 \\
\hline Slc39a1 & $t(1,4)=1.9$ & $1.24 \pm 0.13$ & 3,3 & - & .20 \\
\hline Slc39a2 & $t(1,4)=7.1$ & $0.75 \pm 0.04$ & 3,3 & $\downarrow$ & .02 \\
\hline Slc39a3 & $t(1,4)=6.0$ & $1.18 \pm 0.03$ & 3,3 & $\uparrow$ & .03 \\
\hline SIc39a4 & $t(1,4)=5.3$ & $0.82 \pm 0.03$ & 3,3 & $\downarrow$ & .02 \\
\hline Slc39a5 & $t(1,4)=1.3$ & $1.4 \pm 0.30$ & 3,3 & - & .31 \\
\hline Slc39a6 & $t(1,4)=11$ & $0.82 \pm 0.02$ & 3,3 & $\uparrow$ & .01 \\
\hline Slc39a7 & $t(1,4)=2.4$ & $1.2 \pm 0.08$ & 3,3 & - & .14 \\
\hline SIc39a8 & $t(1,4)=18$ & $1.9 \pm 0.05$ & 3,3 & $\uparrow$ & .04 \\
\hline Slc39a9 & $t(1,4)=0.40$ & $1.03 \pm 0.07$ & 3,3 & - & .73 \\
\hline Slc39a10 & $t(1,4)=15$ & $1.04 \pm 0.003$ & 3,3 & - & .78 \\
\hline Slc39a11 & $t(1,4)=0.75$ & $1.2 \pm 0.26$ & 3,3 & - & .53 \\
\hline Slc39a12 & $t(1,4)=2.1$ & $1.35 \pm 0.17$ & 3,3 & - & .17 \\
\hline Slc39a13 & $t(1,4)=97$ & $1.2 \pm 0.002$ & 3,3 & $\uparrow$ & .01 \\
\hline Slc39a14 & $t(1,4)=26$ & $0.81 \pm 0.01$ & 3,3 & $\downarrow$ & .001 \\
\hline Slc40a1 & $t(1,4)=0.68$ & $1.06 \pm 0.08$ & 3,3 & - & .57 \\
\hline Mt1 & $t(1,4)=3$ & $0.62 \pm 0.13$ & 3,3 & $\downarrow$ & .04 \\
\hline Mt2 & $t(1,4)=2$ & $0.76 \pm 0.12$ & 3,3 & - & .18 \\
\hline Mt3 & $t(1,4)=15$ & $0.33 \pm 0.05$ & 3,3 & - & .005 \\
\hline Mt4 & ND & ND & 3,3 & - & ND \\
\hline
\end{tabular}


A

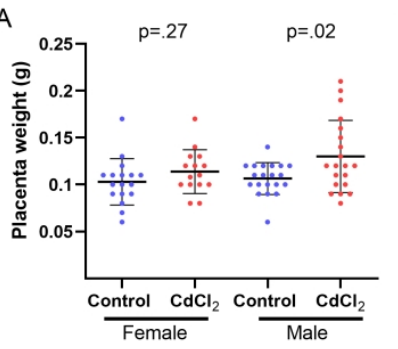

D

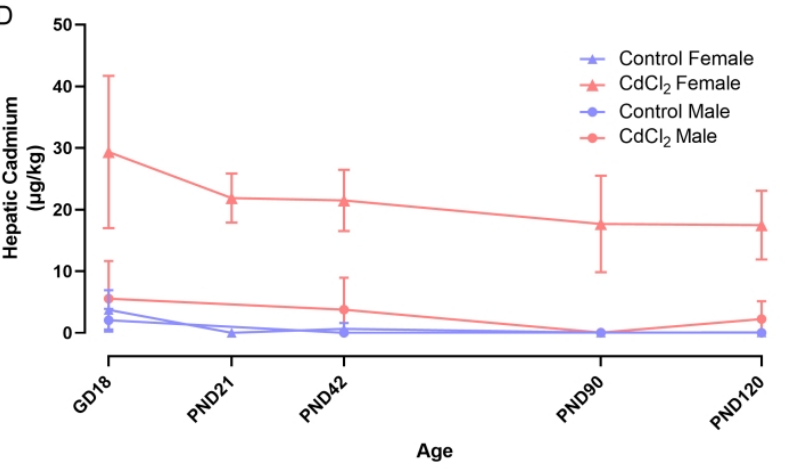

Figure 1
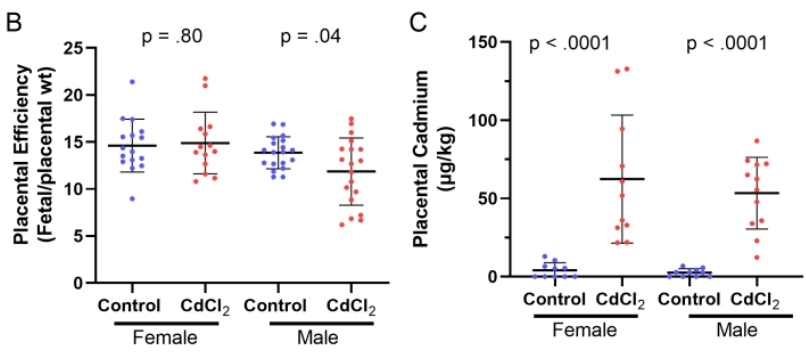

E

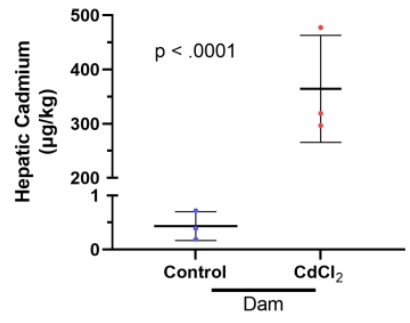

$279 \times 186 \mathrm{~mm}(300 \times 300 \mathrm{DPI})$ 


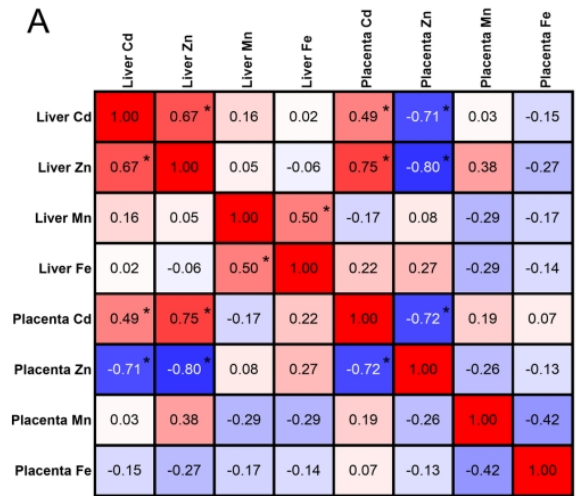

Female
B

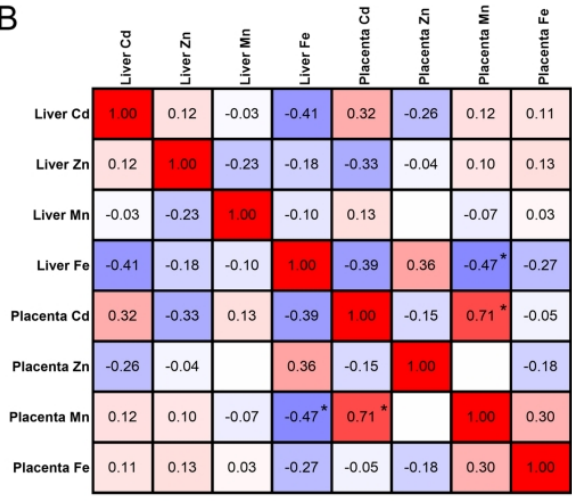

Male

Figure 2

$217 \times 112 \mathrm{~mm}(300 \times 300 \mathrm{DPI})$ 

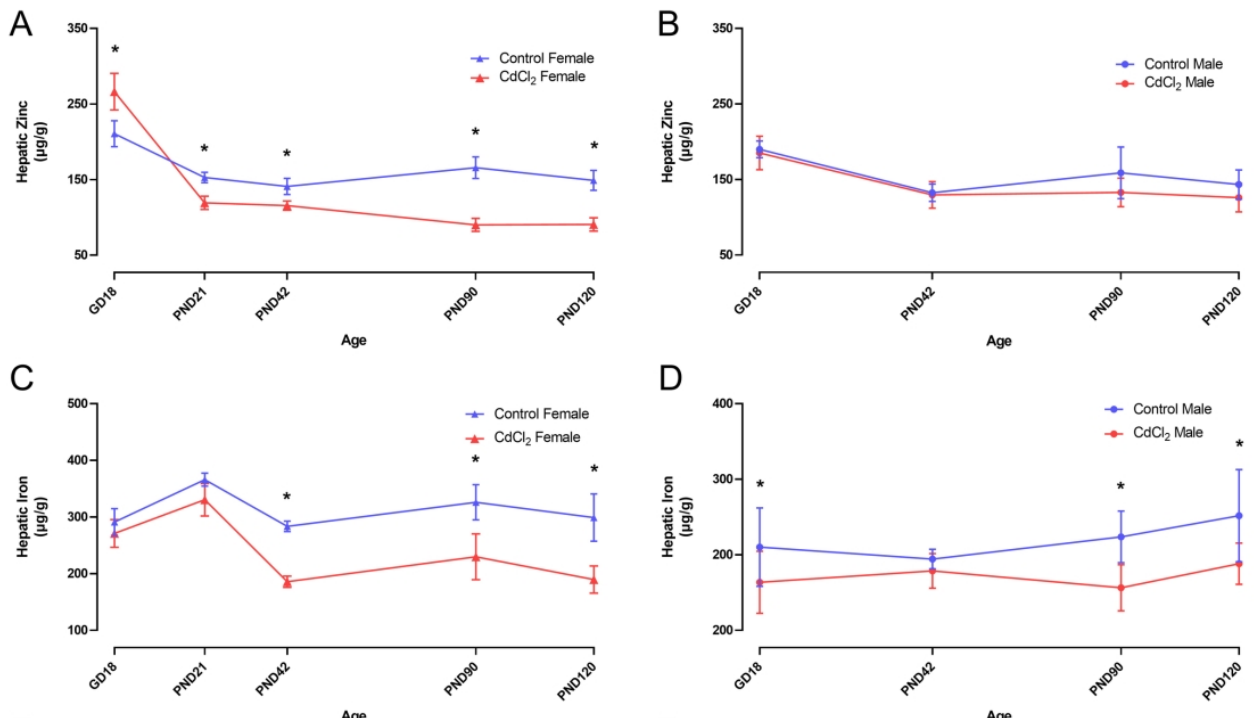

D
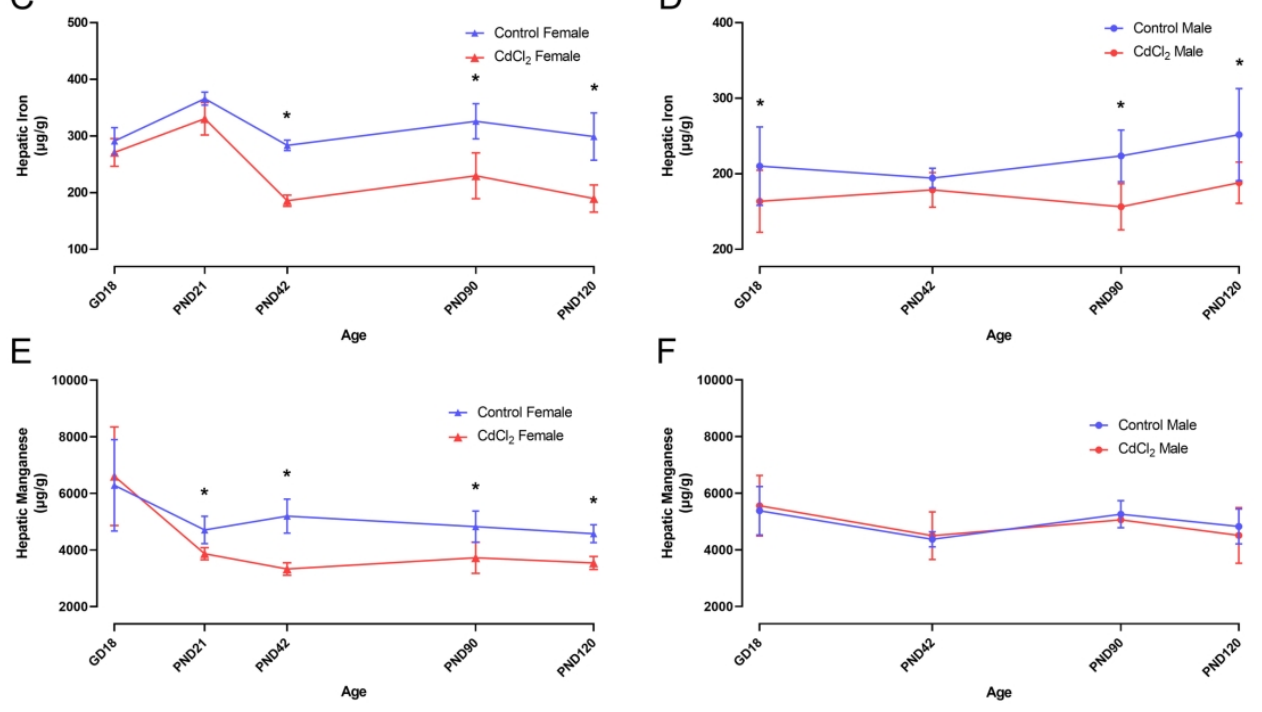

F

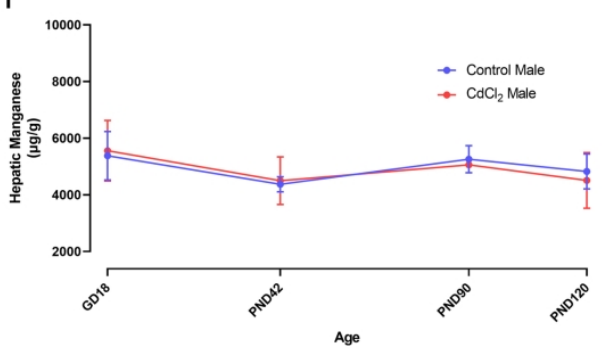

Figure 3

$210 \times 182 \mathrm{~mm}(300 \times 300$ DPI $)$ 


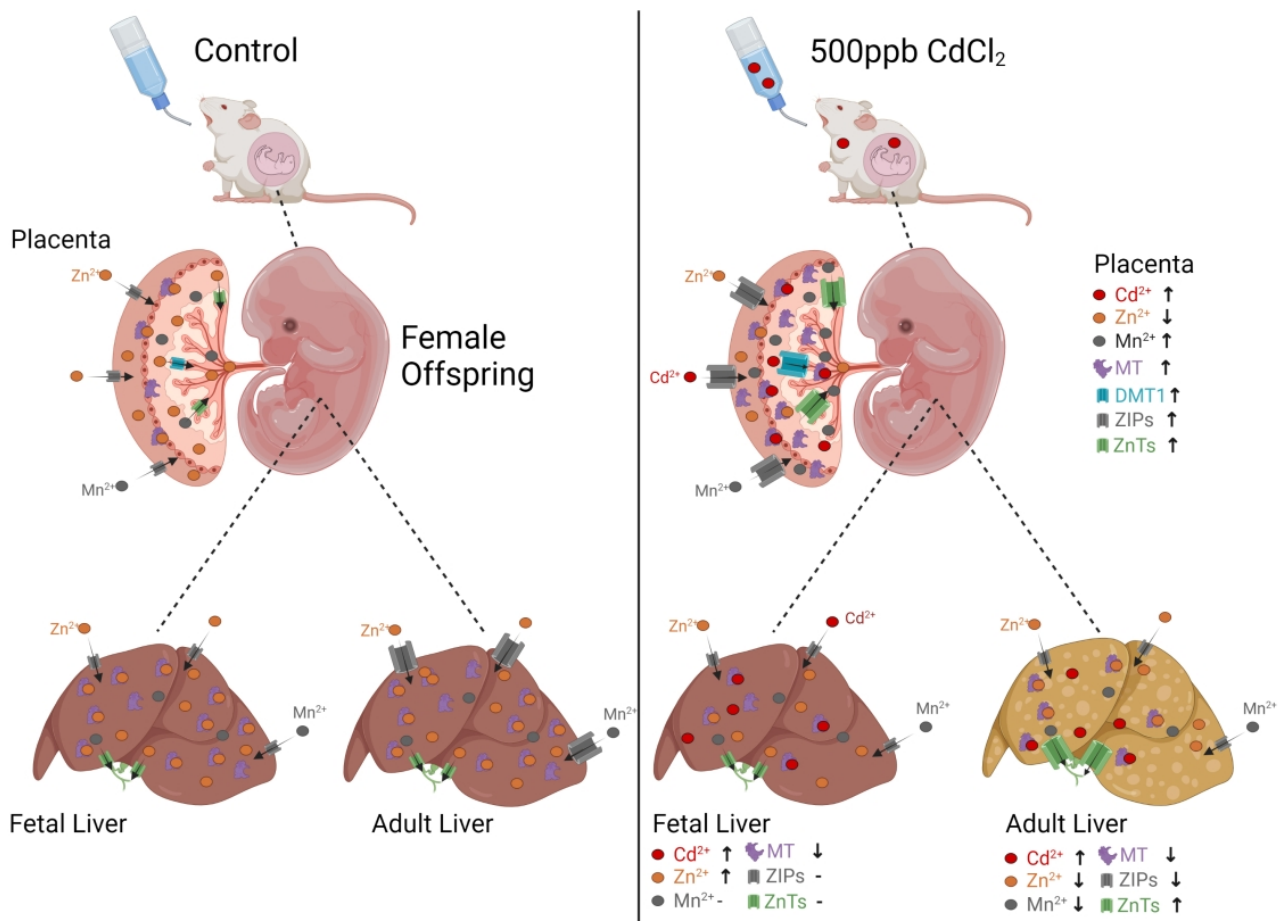

Figure 4

$645 \times 452 \mathrm{~mm}(118 \times 118$ DPI $)$ 


\section{Gestational Cd Exposure in the CD-1 Mouse Sex-Specifically Disrupts Essential Metal lon Homeostasis}

Thomas W. Jackson (ORCiD: 0000-0002-7996-0412), Oliver Baars (ORCiD: 0000-0002-4644-5086), and Scott M. Belcher (ORCiD: 0000-00021196-3705)*

\section{Contents:}

Supplemental Table 1.

Supplemental Table 2.

Supplemental Table 3.

Supplemental Table 4. 
Supplemental Table 1. Gene list for qRT-PCR analyses.

\begin{tabular}{|c|c|c|c|}
\hline Gene Name & $\begin{array}{c}\text { Gene } \\
\text { Symbol }\end{array}$ & ABI Assay \# & $\begin{array}{c}\text { Entrez } \\
\text { Gene ID \# }\end{array}$ \\
\hline actin, beta & Actb & Mm02619580_g1 & 11461 \\
\hline $\begin{array}{l}\text { solute carrier family } 11 \text { (proton-coupled divalent metal ion } \\
\text { transporters), member } 1\end{array}$ & Slc11a1 & Mm00443045_m1 & 18173 \\
\hline $\begin{array}{l}\text { solute carrier family } 11 \text { (proton-coupled divalent metal ion } \\
\text { transporters), member } 2\end{array}$ & Slc11a2 & Mm00435363_m1 & 18174 \\
\hline solute carrier family 25 (mitochondrial carrier), member 16 & Slc25a16 & Mm00613555_m1 & 73132 \\
\hline solute carrier family 30 (zinc transporter), member 1 & Slc30a1 & Mm00437377_m1 & 22782 \\
\hline solute carrier family 30 (zinc transporter), member 2 & Slc30a2 & Mm01185317_m1 & 230810 \\
\hline solute carrier family 30 (zinc transporter), member 3 & Slc30a3 & Mm00442148_m1 & 22784 \\
\hline solute carrier family 30 (zinc transporter), member 4 & Slc30a4 & Mm01268687_m1 & 22785 \\
\hline solute carrier family 30 (zinc transporter), member 5 & Slc30a5 & Mm00458158_m1 & 69048 \\
\hline solute carrier family 30 (zinc transporter), member 6 & Slc30a6 & Mm00460610_m1 & 210148 \\
\hline solute carrier family 30 (zinc transporter), member 7 & Slc30a7 & Mm00458239_m1 & 66500 \\
\hline solute carrier family 30 (zinc transporter), member 8 & Slc30a8 & Mm00555793_m1 & 239436 \\
\hline solute carrier family 30 (zinc transporter), member 9 & Slc30a9 & Mm00618278_m1 & 109108 \\
\hline solute carrier family 30 (zinc transporter), member 10 & Slc30a10 & Mm01315481_m1 & 226781 \\
\hline solute carrier family 39 (zinc transporter), member 1 & Slc39a1 & Mm01605921_g1 & 30791 \\
\hline solute carrier family 39 (zinc transporter), member 2 & Slc39a2 & Mm01314597_g1 & 214922 \\
\hline solute carrier family 39 (zinc transporter), member 3 & Slc39a3 & Mm00460290_m1 & 106947 \\
\hline solute carrier family 39 (zinc transporter), member 4 & Slc39a4 & Mm00511151_m1 & 72027 \\
\hline solute carrier family 39 (metal ion transporter), member 5 & Slc39a5 & Mm00511105_m1 & 72002 \\
\hline solute carrier family 39 (zinc transporter), member 6 & Slc39a6 & Mm00507295_m1 & 106957 \\
\hline solute carrier family 39 (zinc transporter), member 7 & Slc39a7 & Mm00433930_m1 & 14977 \\
\hline solute carrier family 39 (zinc transporter), member 8 & Slc39a8 & Mm00470855_m1 & 67547 \\
\hline solute carrier family 39 (zinc transporter), member 9 & Slc39a9 & Mm00470907_m1 & 328133 \\
\hline solute carrier family 39 (zinc transporter), member 10 & Slc39a10 & Mm00554174_m1 & 227059 \\
\hline solute carrier family 39 (metal ion transporter), member 11 & Slc39a11 & Mm04206888_m1 & 69806 \\
\hline solute carrier family 39 (zinc transporter), member 12 & Slc39a12 & Mm01325273_m1 & 277468 \\
\hline solute carrier family 39 (metal ion transporter), member 13 & Slc39a13 & Mm01329757_m1 & 68427 \\
\hline solute carrier family 39 (zinc transporter), member 14 & Slc39a14 & Mm01317439_m1 & 213053 \\
\hline solute carrier family 40 (iron-regulated transporter), member 1 & Slc40a1 & Mm01254822_m1 & 53945 \\
\hline
\end{tabular}

Supplementary Material 


\begin{tabular}{|l|c|c|c|}
\hline metallothionein 1 & Mt1 & Mm00496660_g1 & 17748 \\
\hline metallothionein 2 & Mt2 & Mm00809556_s1 & 17750 \\
\hline metallothionein 3 & Mt3 & Mm00496661_g1 & 17751 \\
\hline metallothionein 4 & Mt4 & Mm00485227_m1 & 17752 \\
\hline
\end{tabular}




\begin{tabular}{|c|c|c|c|}
\hline \multicolumn{4}{|c|}{ Supplemental Table 2. PCR and pyrosequencing primers (5' - $\left.3^{\prime}\right)$} \\
\hline $\begin{array}{l}\text { Gene } \\
\text { Symbol }\end{array}$ & Forward Primer & Reverse Primer & Sequencing Primer \\
\hline Slc30a10 & GAGGGAGAATTGAGGGAAGAATAA & ACTCCTAACTCCAACACAACAATAACT $^{*}$ & GAAAGGTATTTGTTATATTAGAGA \\
\hline Slc30a10 & TGAAGTAGAGAGTAGTGAGGAAGATTG & ACTCCTTCAACATACTATCAAACCTAATCT* & GTAGTAGTAGGTGGTATTGG \\
\hline Slc30a10 & GGGGGGAGGTTTTGGAGTTTATT & TAAAACCACTCCTACAAACTCTAATC* & AGTTTATTTTTTGTTGTAGGT \\
\hline Slc30a10 & TGGTTGTAGTAGTTTTTTGGGGATAT & TTCCTCACTACCCTCTACTTCACCATCT* & GTTTTTTGGGGATATTTTAAAG \\
\hline Slc25a16 & AGTAGGAAATTAGGGATTTTGAGTGT & CAAAACACTAAACAACACCATAACT* ${ }^{*}$ & GTTATGGGTATTATTTGGT \\
\hline Slc25a16 & ATGGTGTTGTTTAGTGTTTTGTAAG & ACTTCAACACCCAACCCC ${ }^{*}$ & GTGTTTTGTAAGTTGGTAG \\
\hline Slc25a16 & ATGGTGTTGTTTAGTGTTTTGTAAG* & ACTTCAACACCCAACCCC & AAAAAAAAACCCAACCAATAAAAAT \\
\hline Slc25a16 & GGATTTAGGGGTTGGGTGTTGA & CCACCTAAAAAATCCTATTTTCAACCTTA* & GGTTGGGTGTTGAAG \\
\hline Slc39a6 & AGGTTAGAAGGGATTGGGAAT & AACCAAACTAAACTAAAATCCTAAC ${ }^{*}$ & GTTTTTTTTAAAGTAGGATAAT \\
\hline Slc39a6 & GGTAAGAGGGATTAGTTGGATTTAGAG & АCTCСТАСАССССТАAАATAT* & GGATTAGTTGGATTTAGAGTT \\
\hline Slc39a14 & GGGTTTTGGATAGTGAGGT & ACAATCAAATACTACCAAAACTAAACT* & GGTGGGGGTTGGAGA \\
\hline Slc39a14 & TGTGTTTTGGGGTTTTAGAAAGT & TAAACCCAATCCTAATAACACCTAATTAC* & AAGTTTATTTTAGTTTTTTTGAGTA \\
\hline Slc39a14 & TGTTATTAGGATTGGGTTTAGGG* & AAAACCCACCCACTCAATAACTATAT & GGATTGGGTTTAGGGA \\
\hline Slc39a14 & ATTTAGGGTTTTGTAGTTGAAGGGATAG* & САСТСССТАААСССААТССТ & СССТАААСССААТССТА \\
\hline Slc39a14 & GGTGTTATTAGGATTGGGTTTAGG & AAAACCCACCCACTCAATAACTATATR* & GTTTTTATTTGAAGTTTTTTAG \\
\hline Mt1 & TGTGTATATTGGAGTTTTAGGGAGTTT & ATAACССТTAAAAAACAACСТАСССТСТT* & TGGAGTTTTAGGGAGTTTTGTAT \\
\hline Mt1 & AGGAATTTTAGGAAAGGAGAAGT & AACATCATATCCCTATAATACTTTCC ${ }^{*}$ & GGAGAAGTTGAGGTTAT \\
\hline
\end{tabular}


Supplementary Material

\begin{tabular}{|c|c|c|c|c|c|c|c|c|c|c|}
\hline Dam & Test & Statistic & p-value & $\begin{array}{l}\text { Effect } \\
\text { size }\end{array}$ & $\begin{array}{l}\text { Effect } \\
\text { size }\end{array}$ & $\mathrm{N}=$ Control $; \mathrm{Cd}$ & & & & \\
\hline Dam Hepatic Cd & Student t-test & $t(4)=6.4$ & .004 & Cohen d & 5.2 & $3 ; 3$ & & & & \\
\hline Offspring & Test & Statistic & p-value & $\begin{array}{c}\text { Effect } \\
\text { size } \\
\text { test }\end{array}$ & $\begin{array}{l}\text { Effect } \\
\text { size }\end{array}$ & Post-hoc test & $\begin{array}{l}\text { Female } \\
\text { p-value }\end{array}$ & $\begin{array}{c}\text { Male } \\
\text { p-value }\end{array}$ & $\begin{array}{l}N=\text { Female } \\
\text { (control;Cd) }\end{array}$ & $\begin{array}{c}\mathrm{N}=\text { Male } \\
\text { (control;Cd) }\end{array}$ \\
\hline $\begin{array}{l}\text { GD18 Placenta } \\
\text { Weight }\end{array}$ & ANOVA & $F(3,69)=2.8$ & .03 & $\eta^{2}$ & .14 & Tukey & .27 & .02 & $17 ; 14$ & $20 ; 22$ \\
\hline Placental Efficiency & ANOVA & $F(3,69)=3.9$ & .01 & $\eta^{2}$ & .15 & Tukey & .80 & .04 & $17 ; 14$ & $20 ; 22$ \\
\hline GD18 Placenta Cd & ANOVA & $F(3,39)=18$ & $<.0001$ & $\eta^{2}$ & .61 & Tukey & $<.0001$ & $<.0001$ & $10 ; 11$ & $10 ; 12$ \\
\hline GD18 Hepatic Cd & ANOVA & $F(3,34)=29$ & $<.0001$ & $\eta^{2}$ & .75 & Tukey & $<.0001$ & .34 & $9 ; 11$ & $8 ; 10$ \\
\hline PND21 Hepatic Cd & Student t-test & $t(6)=11$ & $<.0001$ & Cohen d & 7.8 & - & - & - & $4 ; 4$ & - \\
\hline PND42 Hepatic Cd & ANOVA & $F(3,13)=35$ & $<.0001$ & $\eta^{2}$ & .89 & Tukey & $<.0001$ & .15 & $5 ; 4$ & $4 ; 4$ \\
\hline PND90 Hepatic Cd & ANOVA & $F(3,16)=29$ & $<.0001$ & $\eta^{2}$ & .84 & Tukey & $<.0001$ & .98 & $6 ; 4$ & $4 ; 6$ \\
\hline PND120 Hepatic Cd & ANOVA & $F(3,13)=29$ & $<.0001$ & $\eta^{2}$ & .87 & Tukey & $<.0001$ & .34 & $5 ; 4$ & $3 ; 5$ \\
\hline GD18 Placenta Zn & ANOVA & $F(3,39)=89$ & $<.0001$ & $\eta^{2}$ & .87 & Tukey & $<.0001$ & .78 & $10 ; 11$ & $10 ; 12$ \\
\hline GD18 Hepatic Zn & ANOVA & $F(3,34)=36$ & $<.0001$ & $\eta^{2}$ & .76 & Tukey & $<.0001$ & .62 & $9 ; 11$ & $8 ; 10$ \\
\hline PND21 Hepatic Zn & Student t-test & $t(6)=6.0$ & .0009 & Cohen d & 4.3 & - & - & - & $4 ; 4$ & - \\
\hline PND90 Hepatic Zn & ANOVA & $F(3,16)=13$ & .0002 & $\eta^{2}$ & .70 & Tukey & $<.0001$ & .07 & $6 ; 4$ & $4 ; 6$ \\
\hline PND120 Hepatic Zn & ANOVA & $F(3,13)=12$ & .0004 & $\eta^{2}$ & .72 & Tukey & $<.0001$ & .12 & $5 ; 4$ & $3 ; 5$ \\
\hline GD18 Placenta Fe & ANOVA & $F(3,39)=0.7$ & .55 & $\eta^{2}$ & - & Tukey & - & - & $10 ; 11$ & $10 ; 12$ \\
\hline GD18 Hepatic Fe & ANOVA & $F(3,34)=3$ & .04 & $\eta^{2}$ & .21 & Tukey & .22 & .01 & $9 ; 11$ & $8 ; 10$ \\
\hline PND21 Hepatic Fe & Student t-test & $t(6)=2.3$ & .06 & Cohen d & - & - & - & - & $4 ; 4$ & - \\
\hline PND42 Hepatic Fe & ANOVA & $F(3,13)=49$ & $<.0001$ & $\eta^{2}$ & .92 & Tukey & $<.0001$ & .15 & $5 ; 4$ & $4 ; 4$ \\
\hline PND90 Hepatic Fe & ANOVA & $F(3,16)=10$ & .0007 & $\eta^{2}$ & .65 & Tukey & .0004 & .007 & $6 ; 4$ & $4 ; 6$ \\
\hline PND120 Hepatic Fe & ANOVA & $F(3,13)=11$ & .0006 & $\eta^{2}$ & .72 & Tukey & .001 & .04 & $5 ; 4$ & $3 ; 5$ \\
\hline GD18 Placenta Mn & ANOVA & $F(3,39)=5.0$ & .005 & $\eta^{2}$ & .28 & Tukey & .03 & .005 & $10 ; 11$ & $10 ; 12$ \\
\hline GD18 Hepatic Mn & ANOVA & $F(3,34)=1.7$ & .19 & $\eta^{2}$ & - & Tukey & - & - & $9 ; 11$ & $8 ; 10$ \\
\hline PND21 Hepatic Mn & Student t-test & $t(6)=3.2$ & .02 & Cohen d & 2.2 & - & - & - & $4 ; 4$ & - \\
\hline PND42 Hepatic Mn & ANOVA & $F(3,13)=8.5$ & .002 & $\eta^{2}$ & .66 & Tukey & .0002 & .75 & $5 ; 4$ & $4 ; 4$ \\
\hline PND90 Hepatic Mn & ANOVA & $F(3,16)=5.5$ & .008 & $\eta^{2}$ & .51 & Tukey & .008 & .25 & $6 ; 4$ & $4 ; 6$ \\
\hline
\end{tabular}




\begin{tabular}{|c|c|c|c|c|c|}
\hline PND120 Hepatic Mn & ANOVA & $F(3,13)=4.3$ & .03 & Tukey & .02 \\
\hline & & \multicolumn{4}{|c|}{$\begin{array}{l}\text { Supplemental Table } 4 \text {. CpG methylation of putative promoter regions } \\
\text { upstream of metallothionein and metal ion transporter genes in female } \\
\text { CD-1 mice }\end{array}$} \\
\hline & & Gene & Control & $\mathrm{CdCl}_{2}$ & $\begin{array}{c}\text { \# CpG } \\
\text { Sites }\end{array}$ \\
\hline & & Slc30a10 & $1.64 \pm 0.88(8)$ & $1.26 \pm 0.93(8)$ & 15 \\
\hline & & Slc25a16 & $0.60 \pm 0.35(8)$ & $0.48 \pm 0.40(8)$ & 27 \\
\hline & & Slc39a6 & $0.78 \pm 0.42(8)$ & $0.45 \pm 0.29(8)$ & 12 \\
\hline & & Slc39a14 & $1.13 \pm 1.26(8)$ & $2.06 \pm 1.58(8)$ & 14 \\
\hline & & Mt1 & $23.8 \pm 17.0(7)$ & $26.2 \pm 14.8(6)$ & 12 \\
\hline & & \multicolumn{4}{|c|}{$\begin{array}{l}\text { Values represent group mean }(\%) \pm S E M \text {; the number of samples } \\
\text { analyzed is shown in parenthesis. }{ }^{*} p<.05 . \mathrm{CdCl} 2=500 \mathrm{ppb} \\
\text { gestational Cadmium Chloride }\end{array}$} \\
\hline
\end{tabular}

